Institutions

Markets

Technologies

IMT

INSTITUTE

FOR ADVANCED

STUDIES

LUCCA
\#05

2012

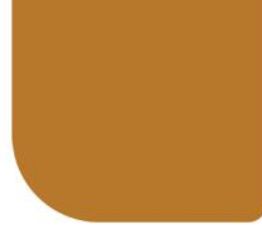

ISSN 2279-6894

IMT LUCCA EIC WORKING

PAPER SERIES 05

October 2012

Updated on July 2013

\title{
Technology and the Era of the Mass Army
}

Massimiliano Gaetano Onorato

Kenneth Scheve

David Stasavage 
ISSN 2279-6894

IMT LUCCA EIC WORKING PAPER SERIES \#05/2012

(C) IMT Institute for Advanced Studies Lucca

Piazza San Ponziano 6, 55100 Lucca

Research Area

Economics and institutional change

\section{Technology and the Era of the Mass Army}

\section{Massimiliano Gaetano Onorato}

IMT Institute for Advanced Studies Lucca

\section{Kenneth Scheve}

Stanford University

David Stasavage

New York University 


\section{Technology and the Era of the Mass Army ${ }^{1}$}

\author{
Massimiliano Gaetano Onorato \\ IMT Lucca
}

\author{
Kenneth Scheve \\ Stanford University
}

David Stasavage

New York University

July 2013

\footnotetext{
${ }^{1}$ We thank Bernd Beber, Pablo Beramendi, Oeindrila Dube, Jim Fearon, Peter Gourevitch, Bob Kaufman, David Lake, Josh Ober, Maggie Peters, Pablo Querubin, Dan Reiter, Jack Snyder, two anonymous reviewers, and seminar participants at Columbia, Stanford, Yale, UCLA, Michigan, Minnesota, Duke, Cornell, the LSE, Namur, the Paris School of Economics, the Juan March Institute, Sciences-Po, NYU Abu Dhabi, Alicante, and EPSA 2012 for comments on a previous draft. We also thank Erdem Aytac, Quintin Beazer, Nikhar Gaikwad, Young Joe Hur, and Yiming Ma for excellent research assistance and Sonke Ehret, John Lynn, Jim Snyder, and Bruce Russett for helpful advice. We are grateful for financial support from the MacMillan Center for International \& Area Studies, and the Institution for Social and Policy Studies. David Stasavage is also grateful to the Sciences-Po economics department for inviting him as a visitor.
} 


\begin{abstract}
War and the extent of mass mobilization for war has a significant impact on a wide variety of economic and political development outcomes. In this paper, we investigate to what extent technological change has influenced the choice by governments to field mass armies. Focusing on a sample of thirteen great powers between 1600 and 2000 we argue that changes in transport and communications technology were the single most important factor that ushered in the era of the mass army and subsequently led to its demise. During the nineteenth century the development of the railroad made it possible for the first time to mobilize and feed armies numbering in the millions. During the late twentieth century further advances in transport and communications technology made it possible to deliver explosive force from a distance and with precision, making mass armies less desirable. We find strong support for our technological interpretation using a new data set that measures army size, population mobilization, and methods of recruitment from the beginning of the seventeenth century. In so doing we also consider several other plausible determinants of military mobilization. Contrary to what is often suggested by scholars, we find little evidence that the French Revolution and the invention of the concept of "the nation in arms" was associated with a substantial increase in levels of mobilization across nations. Even for the French case alone, the magnitude of what is sometimes referred to as the "Napoleonic watershed" was smaller than what is often believed.
\end{abstract}




\section{Introduction}

War, and in particular mass warfare, matters for a wide variety of important economic outcomes. The mass wars of the twentieth century were associated with a dramatic drop in top income shares in participant countries. ${ }^{1} \quad$ They were also associated with a significant shift towards

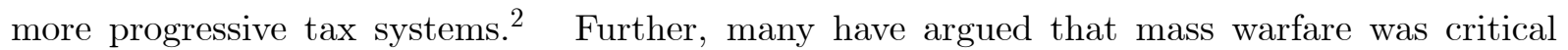
in ushering in the era of the welfare state. ${ }^{3}$ Finally, it is also widely suggested that war participation prompts states to build bureaucratic capacity, and mass warfare is certainly no exception. ${ }^{4}$ Given that mass warfare matters for all of these economic outcomes, in addition to its more obvious destructive effects on capital and human life, it makes sense to ask what factors over time have determined the ability to and desirability for a state to field a mass army. One tradition among historians and economic historians suggests that over the centuries, the nature and scale of warfare has depended critically upon technological change, whether it be the introduction of the iron stirrup, use of gunpowder technology, or the invention of new styles of fortification. ${ }^{5}$ While scholars in this tradition have focused primarily on investigating the Military Revolution of the early modern period, in this paper we suggest that a similar focus on technological change may help us explain the incidence of mass warfare over a more recent period. We argue that changes in communications and transport technology, and in particular the invention of the railroad, constituted the most important factor in ushering in an era of mass warfare where armies numbered in the millions. Subsequently, further changes in communications and transport technologies that made it possible to remotely deliver explosive force have made it less necessary and less desirable to mobilize a mass army. The implication then is that the era of the mass army was a bounded period dependent on a specific state of technological development.

Military historians have long pointed to the importance of the railroad for the scale of

\footnotetext{
${ }^{1}$ Piketty (2001), Atkinson and Piketty (2007).

${ }^{2}$ Scheve and Stasavage $(2010,2012)$.

${ }^{3}$ Titmuss $(1950,1958)$.

${ }^{4}$ Tilly (1975, 1990), Besley and Persson (2009), and Gennaioli and Voth (2011). See Dincecco and Prado (2012) for an empirical analysis, as well as the discussion by O'Brien (2011) of the British case.

${ }^{5}$ For a recent example see Hoffman (2011). For other prominent examples see Roberts (1956), White (1962), Bean (1973) and Parker (1976).
} 
military mobilization, but this argument has yet to be exposed to a systematic test. ${ }^{6}$ Though it would hardly be surprising to see from this that railroads mattered, we still need to establish just how much they mattered. We follow the work of military historians in suggesting that prior to the invention of the railroad, large armies faced a fundamental problem of logistics. While soldiers could transport themselves, their supplies had to be carried. The long-standing alternative to this was for armies to forage, but this then meant that the size of an army was constrained by the agricultural productivity of the land across which it marched. The adoption of the railroad by militaries changed this situation completely as it was now possible to transport men, munitions, and food in such quantities and with such speed that armies numbering in the millions could become a reality. The parallel development of the telegraph made it possible to command operations on this scale. Armies representing ten percent or more of a society's total population suddenly became feasible, and to find such numbers of individuals, states were obliged to recruit from a broad segment of society.

While descriptions of military mobilization over the long run generally refer to a secular trend towards increasing army size, by now any satisfactory explanation ought to also be able to account for the more recent trend away from mass armies. There are no doubt multiple plausible explanations here, one of which would be changing norms. Without dismissing such accounts, in what follows we suggest that even in the absence of these factors, developments in communications and transport technology may have greatly reduced incentives for states to mobilize mass armies. The inventions of the industrial revolution made it possible to move men and their supplies with unprecedented speed. More recent developments in communications and transport technologies involving the gyroscope, the laser, radar, the computer, and satellites have made it possible to deliver explosive force remotely with unprecedented effectiveness. It would be hard to argue that the invention of nuclear weapons did not also play a role in ending the era of the mass army, but it should be remembered that as early as 1946, Bernard Brodie observed that in the nuclear age the development of missile and guidance technology would be critical. ${ }^{7}$

\footnotetext{
${ }^{6}$ See in particular Pratt (1915), van Creveld (1977, 1989), Westwood (1980), Wolmar (2010), Mcneill (1984) p.223), Fischer (1925), Fuller (1998), and Ropp (1959 p.161). In terms of technology, political scientists have previously emphasized the importance of railroads for military mobilization, but in doing so they have focused above all on the effect of rail transport on the offense-defense balance. See in particular Fearon (1997), Sagan (1986), Shimshoni (1990), van Evera (1984), Snyder (1984), and Jervis (1978).

${ }^{7}$ Brodie (1946).
} 
In our empirical tests we also take account of several alternative hypotheses. The most prominent of these is the idea that the French Revolution and the invention of the concept of "the nation in arms" constituted a structural break. After this date, or so it's proponents would suggest, it was possible to mobilize armies on a scale previously thought unimaginable. ${ }^{8}$

To test our argument as well as several alternatives we have compiled a new data set that records army sizes, levels of military mobilization (army size/total population), and recruitment methods for thirteen great powers over the period from 1600 to 2000 . We adopt the classification of great powers first proposed by Jack Levy (1983). Our army size data derives from the Correlates of War data set for the period since 1815. For the period between 1600 and 1815 we have constructed measures of army size by referring to a wide range of historical sources, all of which are listed in the appendix to this paper. When combined with available estimates of population, these also allow us to construct mobilization levels for this period.

In order to test our hypothesis about the impact of shifts in communications and transport technology, we first propose an indirect test and then a more direct test. Using a pooled regression that includes country fixed effects, we regress either military size or military mobilization on an indicator variable that takes a value of 1 beginning in 1859, the first year that railways were used in a major way in combat, as well as on an indicator variable that takes a value of 1 beginning in 1970, a threshold year in the development of cruise missile technology. Finally, the regressions also include an indicator variable that takes a value of 1 beginning in 1789 . This tests the alternative hypothesis that the invention of the idea of "the nation in arms" led to an increase in army size and mobilization levels.

When we use either military size or military mobilization as a dependent variable, we observe, consistent with our core hypothesis, that the year 1859 was associated with a large and statistically significant shift upward in both of these dependent variables, whereas the year 1970 was associated with a shift downward in both of these variables. In contrast, there is no evidence in our pooled regressions that the year 1789 was associated with a statistically significant shift upward in either army sizes or levels of mobilization.

\footnotetext{
${ }^{8}$ This argument is particularly prominent among political scientists including Posen (1993), Snyder (2000), Cederman, Sornette, and Warren (2011), Fearon (1997), Van Evera (1998), and Walt (1992). Specialists in military affairs who emphasize this point include Cohen (1996), Mahnken (2011), Liddell Hart (1954), Krepinivich (2002), and of course Clausewitz (1832).
} 
Given the results of the indirect test of our transport and communications hypothesis, we also propose a more direct test. To do so we augment the previously described regressions by including a variable measuring the number of kilometers of railway existing in a given country in a given year and a variable indicating whether or not a country has acquired cruise missiles in a given year. We also add control variables for population, GDP per capita, nationalism, political regime, and state institutions. We model unobserved time effects through either a common or country-specific linear time trend. We find in these estimates that the extent of a country's railway network is significantly positively correlated with the magnitude of military mobilization while the presence of cruise missiles is significantly negatively correlated with mobilization. Importantly, we also observe that when these variables are introduced into the regression, our indicator variables for post-1859 and post-1970 years are no longer statistically significant, and each coefficient drops substantially in magnitude. We show that these results are robust to changes in the covariate profile, operationalization of key variables, and functional form assumptions. For the railroad results, we also show that the estimates are robust to expanding the sample beyond great power countries and to changing the sample period. We also explore difference-in-difference comparisons within a country by looking at differences in navy and army growth in the UK before and after railroads became widely used for military purposes. Taken together, these analyses provide strong evidence for the importance of the railroad in ushering in the era of the mass army. Though our results for cruise missiles are subject to more caveats, our results here are nonetheless consistent with the view that communications and technology advances in the second half of the 20th century led countries to field substantially smaller forces in their conflicts. Finally, our pooled analysis further explores the role of nationalism by exploiting the idea that states find it difficult to instill national loyalties before the introduction of mass schooling (Darden, forthcoming) and adopting literacy rates as a proxy for nationalism. We do not find evidence of a positive partial correlation betwen literacy rates and either of our measures of mobilization. This result is consistent with the lack of a break point in either series near 1789. Although our pooled results do not suggest a large and early role for nationalism in bringing about the era of mass warfare, our evidence on this point is somewhat indirect. Moreover, we present evidence of a positive interaction between our nationalism and 
railroad measure. This finding is consistent with the idea that nationalism played a role in making citizens willing to fight but it was only after the railroad made large armies feasible did it have a significant effect on mobilization.

We refrain from suggesting that the observed correlation between railroad networks and army size is definitive evidence of the precise causal mechanism that we have in mind. An alternative might be that states that wanted to have large armies also built extensive railroad networks whereas states that chose not to have large armies refrained from building extensive railway networks. If this was the case then it would imply that in a regression of army size (or mobilization) on railroad network size, we would get a biased estimate of the true effect of the latter on the former. In what follows, however, we present evidence from Bogart (2009) to show that the coefficients on the measures we use for kilometers of railway are unlikely to be biased in this manner. The key reason is that governments that anticipated military conflict tended to nationalize railways, influence their management, and influence choices of where to locate railway lines, but with a few notable exceptions, governments did not build more kilometers of railway in anticipation of conflict. This provides a further important reason for using our railroad kilometers measure as opposed to an alternative variable that might also take into account further characteristics of a railroad network such as its organization and degree of centralized control. We should acknowledge, however, that we have no such assurance of plausible exogeneity for our cruise missile tests.

In addition to our pooled analyses, we also discuss the history of French mobilization in greater depth. We focus on France because it is the case that has most informed the thinking of many scholars about the evolution of mass armies and their political determinants. Our discussion of France suggests that even in this case, it is clear that the magnitude of the influence of the French Revolution and Napoleonic era on army size and mobilization was relatively small and the era of the mass army was a late 19th and 20th century phenomenon that coincided with and depended on the technological innovations of the industrial revolution.

Finally, we also consider the methods through which armies were recruited in the period between 1600 and 2000. It is common to see universal conscription as an invention that made the mass army possible. We will argue below that the evidence on military recruitment actually 
fits more closely with our alternative, technology based interpretation. The causal chain may actually lead from technological change, to universal conscription, to the emergence of mass armies. More recent technological change may have had the exact opposite development. Our regression results are consistent with the former claim, though the evidence for the latter is somewhat weaker.

In the remainder of this paper, we proceed as follows. Section 2 outlines our argument that changes in communications and transport technology, and in particular the invention of the railroad, constituted the most important factor in ushering in an era of mass warfare. In Section 3 we consider alternative explanations. In Section 4, we present a new comparative data set on the size of the military in thirteen great power countries from 1600 to 2000, and we also consider the methods by which these armies were recruited. Section 5 then presents our empirical evaluation of our argument and Section 6 considers the French case in greater detail. Section 7 concludes.

\section{Technology and the Mass Army}

The core question we ask in this paper is what factors have led the great powers to field mass armies. Since we are examining a long stretch of history, there are undoubtedly multiple factors that have been at play, and below we will discuss those that have been most heavily emphasized in previous scholarship. Before doing so, however, we will emphasize a further argument changes in technologies for transport and communications have governed the size of armies that it has been feasible and desirable to mobilize.

In the first instance, fielding a mass army depends on the ability of a state to recruit a sufficiently large set of individuals. It also depends on two further factors. First, a state must have the ability to actually deploy troops and to keep them supplied. Second, a state that has the ability to recruit a mass army must also prefer this format of military force to one in which a more limited number of individuals serve. In what follows we will argue that prior to the invention of the railroad, it was physically impossible for states to field armies numbering in the millions. Even had it been possible to raise, transport, and support an army of this size, 
before the invention of the telegraph and telephone, it would have been extremely difficult to exercise command. It was thus the application of the inventions of the industrial revolution that allowed a broad set of states for the first time to field armies representing up to $10 \%$ of their total population. We will then argue that over recent decades, further developments in transport and communications technology have pushed in the opposite direction. As was recognized (and feared) by Soviet military planners as early as the 1970s, in an environment where weapons can be targeted remotely and with increased precision, a mass army may be increasingly obsolete.

\subsection{A First Revolution - Transporting Men by Railway}

Prior to the adoption of the railway for military purposes, it was possible in theory for a state to recruit a mass army, but fielding it faced several very significant obstacles. ${ }^{9}$ While the soldiers of a mass army could transport themselves by marching to the field of battle, once there they needed to be commanded by some means. In addition, any munitions required for the army needed to be transported. Finally, a mass army — men and horses — needed to be fed. Since antiquity, armies had most often met this last requirement by foraging. But this strategy depended upon the carrying capacity of the land in question. By the eighteenth century the widespread adoption of the potato in Europe had increased the number of calories that could be extracted from a typical plot of agricultural land, but there remained serious limitations on the ability of a very large army, numbering in the hundreds of thousands, to feed itself via either feeding off the land or bringing supplies from the rear via wagon. Napoleon's armies built a reputation for moving quickly. One of the reasons they had to move quickly was that otherwise they would have starved after exhausting all nearby resources. ${ }^{10}$ Prior to the invention of the railway, an army numbering in the millions would have starved in short order.

The first modern railway was made feasible by the merging of an old technology - the concept of moving goods on rails - together with the principal invention of the industrial revolution - the steam engine. First envisioned at the outset of the nineteenth century, it was not until several decades later that trains capable of carrying passengers were first developed, and several decades

\footnotetext{
${ }^{9}$ This section draws on the studies by Pratt (1915), van Creveld (1977, 1989), Westwood (1980), Fischer (1925), Fuller (1998), and Wolmar (2010).

${ }^{10}$ See van Creveld (1977) on this point.
} 
after that before railways could carry large number of passengers and freight. ${ }^{11}$ Although railways were used in the Crimean war, the authoritative account by Pratt (1915) suggests that the first time they were used in a significant manner was by France during the Italian campaign of 1859. Subsequently, railways played a crucial role in both the American Civil War and the Franco-Prussian War, and of course in World War I. A contemporary observation from 1918 sums up one opinion on the importance of the railway.

What Napoleon would have done if the railroad and motor-truck had been in existence in his day appalls the imagination. His battles were fought with armies which today seem trifling - sixty-two thousand men at Austerlitz; not many more than that at Waterloo. It does not seem to be generally realized that the real reason for the scope of battles nowadays is simply the locomotive. Foch and Hindenburg count their troops by the millions, where Napoleon and Blucher counted theirs by ten thousands, because the steam engine has made it possible to transport and feed a hundred men today as easily as one man a hundred years ago. The new style of warfare is essentially a product, not of trenches, or machine guns, or artillery, but of railroads (Bellows, 1918).

We do recognize that the substantial increase in army size during the second half of the 19th century was made possible by railroads but also made substantially more desirable by the development of the telegraph and widespread use of breach-loading rifles. Further, the invention of the internal combustion engine radically changed how the wars of the first half of the 20th century were fought. However, in many ways, this innovation, as important as it was, largely amplified the effects of the railroad. Moving and supplying large armies became even more feasible and more desirable. Thus, our focus on railroads and technologies for remote delivery seeks to highlight what are in our view the two most important technological innovations influencing the use of mass armies, but our larger argument emphasizes the general importance of technological change in understanding long run trends in the format of military force.

\footnotetext{
${ }^{11}$ See Mokyr (1990) for a discussion of some of these innovations and the obstacles faced.
} 


\section{$2.2 \quad$ A Second Revolution: Remote Delivery of Explosive Force}

Though late nineteenth century advances in transport and communications technologies removed the obstacles to fielding a mass army, there is no reason to necessarily believe that each new advance in this area has led to, or will lead to, the mobilization of ever greater numbers of individuals. The key reason is that if improvements in transport can make it easier to move soldiers to the field of battle, they can also make it easier to deliver and target explosive force from areas withdrawn from the actual field of battle. A wide variety of new technologies have emerged that can allow remote delivery of explosive force and often with great precision. These include the gyroscope, the radar, the laser, and the satellite. ${ }^{12}$ What are the implications of remote delivery of explosive force for levels of mobilization? To quote Major Leonard Litton of the US Air Force, in this era of new weaponry

It is no longer required to bring forces into the same geographical area to bring their effects to bear on the same target and, in fact, on the modern battlefield it may be dangerous as well (Litton 2000,3).

In other words, there may be a straightforward technological explanation suggesting why the era of the mass army is now over. Interestingly, while certain US military planners have advocated the idea that new technologies allow for maintaining the same defensive capability with far fewer men, it was actually Soviet military planners who first highlighted this possibility. Evidence shows that from the late 1970s Soviet planners grew fearful that US advances in the area of precision weapons would render inoperable the principal Soviet war plan which involved quickly pushing a mass army westwards across the European continent. ${ }^{13}$

\subsection{Predicted Effects of The Two Revolutions}

We have laid out an argument suggesting that advances in communications and transport technology, a result of the industrial revolution, helped allow states to mobilize mass armies on a

\footnotetext{
${ }^{12}$ See the contributions by Krepinevich (2002) and Murray and Knox (2001) for discussions of how precision weapons can alter incentives to mobilize mass armies. One should also certainly mention for more recent years the additional technologies for drone airplanes.

${ }^{13}$ See Murray and Knox (2001) on this point.
} 
scale not previously possible. We then suggested how subsequent advances in communications and transport technology have pushed states in the opposite direction by facilitating the remote delivery of explosive force. The implication then is that after a century long period during which technology favored the development of mass armies, the major powers in more recent decades have begun to mobilize smaller armies that in size bear more resemblance to those of the pre-industrial era. There are three observable implications of this argument.

First, in absolute terms we should expect to observe that armies grew larger in size as countries developed railroad networks to transport both men and the materials to keep them supplied. We should likewise expect that as countries gained access to new technologies allowing them to deliver explosive force at a distance and with precision, then armies shrank in size.

Second, we should also expect to observe that as railroad networks expanded, countries were able to mobilize a larger fraction of their overall population. Likewise, the arrival of precision weapons should lead to lower levels of mobilization.

Finally, we might also expect technological change to influence the way in which states recruit their armies. Since the time of Sidgwick (1883) it has been suggested that very large armies will need to be recruited by conscription, which is equivalent to a tax in kind. ${ }^{14}$ The reason is that paying each member of a very large army a market wage would require a level of taxation so high as to impose major deadweight costs on the economy. If this is the case, then we should expect the arrival of the railroad to be associated with a shift to recruitment by conscription and the arrival of precision weapons to increase the likelihood of states reestablishing a professional army. A key feature of this argument is that it applies to conscription regimes in general and not exclusively to regimes of universal conscription. Sidgwick actually believed that social welfare would be maximized with a conscription regime in which those who could earn high incomes in the market economy should be exempted from service. An alternative variant of this prediction regarding recruitment would suggest that the two technological revolutions to which we have referred had their most noticeable impact on the tendency of states to adopt universal conscription, and not necessarily conscription of any form. For the reasons identified by Levi (1997), if individuals are more likely to contribute to a collective project when they believe that

\footnotetext{
${ }^{14}$ See Ross (1994) for a formal treatment of this problem.
} 
all will contribute, then a system of universal conscription is the optimal method for raising a very large army. For this reason we might expect the arrival of the railroad to be associated with a shift to universal conscription and the arrival of precision weapons to be associated with a shift away from this system of recruitment.

\section{Alternative and Complementary Explanations}

\subsection{State Capacity}

The need to raise revenues, which depends on administrative capacity to raise them, is a constraint that has without a doubt influenced the size of armies that states can mobilize. Recruiting volunteer soldiers is easier the better they are paid. Compliance with conscription is also improved with better pay and conditions for soldiers. And, of course, the use of foreign mercenaries depends almost entirely on having revenues available to pay them. Finally, for states to want to raise large armies, they also need to have revenue to arm and supply them. The effectiveness of countries in raising revenue is primarily determined by their wealth and by the transactions costs that rulers face in raising revenue. The importance of national income and wealth for raising revenues and for sovereign borrowing is obvious. Economic resources, however, do not automatically make themselves available to the state. In the first instance raising resources depends on the development of effective bureaucratic institutions of the sort described by James Tracy (1985) for the Netherlands in the sixteenth century and by John Brewer (1988) for the United Kingdom in the eighteenth century. It is difficult to measure the effectiveness of bureaucratic institutions of this sort on a comparative basis and particularly over such a long time period. One option, which we will pursue, is to simply assume that state capacity is correlated with per capita income, a point made abundantly clear by Besley and Persson (2011). A second option, which we will also pursue, is to use the established ability of a state to conduct a national census as a proxy for bureaucratic capacity. 


\section{$3.2 \quad$ Political Rights}

Another alternative hypothesis involves the role of political rights and their association with both the willingness of citizens to fight and the ability of a state to finance a war. Historically, mobilization of a significant share of a country's population for war has often occurred in a context where those who fight are granted new rights that place them on an equal footing with other groups in society. ${ }^{15}$ At the most basic level this would involve being considered a citizen, and at a further level sharing the same rights for voting, representation, and political expression as others. However, mobilization of all does not necessarily have to be associated with a democratic form of government. What it instead implies is that all enjoy the same rights of citizenship and political participation, however extensive or restricted they may be.

At first glance, the equalization of rights has seemed to be a powerful force in enabling states to raise large armies and mobilize a significant share of their populations to fight. In France in the 1790s those who fought were operating in an environment in which privileges long held by nobles had recently been abolished. Similarly, a handful of countries adopted universal suffrage in the context of World War I. Even China provides an example, as in the 1940s those who fought for the Peoples Liberation Army were operating in a context in which privileges of a landlord class had been abolished via extensive land reform. ${ }^{16}$ In our empirical analysis we focus on examining the impact of the extension of voting rights and competitive elections on army size, rates of citizen mobilization, and methods of recruitment.

In addition to focusing on the relationship between democracy and mass mobilization, we can also focus on an earlier set of political rights that many have suggested were associated with the ability to raise revenues and loans for wars. Before the advent of universal suffrage, it was common for European states to have representative assemblies in which a more limited set of citizens could exert influence over policy. At a basic level, a representative assembly could serve as a venue in which a ruler sought citizen consent for taxation, a mechanism that Levi (1988) and previously Sidgwick (1903) suggest allowed for raising more revenue than if a ruler simply

\footnotetext{
${ }^{15}$ This is in fact a very old argument. The earliest known exposition of this claim is in the Pseudo-Xenophon's text "The Constitution of the Athenians", presumed to date from the 5th Century B.C. See Levi (1997) for a discussion of the link between citizenship and conscription in modern times and also Ticchi and Vindigni (2008) for a formal exposition.

${ }^{16}$ See Gittings (1967).
} 
tried to levy taxes without seeking consent. At a second level, a representative assembly could also be given prerogatives over the management of spending, a feature that might make citizens more willing to consent to taxation, as well as more willing to lend if they anticipated that this increased a state's creditworthiness. ${ }^{17}$ We can investigate both of these possibilities using the variables coded and collected by Stasavage $(2010,2011)$ and extended to several other cases.

\subsection{Nationalism}

Finally, there is little doubt that nationalism has been a potent force for states seeking to mobilize their citizens for war. The key question is how important nationalism has been relative to the other factors that have influenced army sizes and the intensity of mobilization. Those who emphasize the importance of nationalism refer to the French Revolution as a key watershed. By inventing the idea of the nation in arms, the French revolutionaries, it is said, ushered in an era where conflict took on a new intensity and scale. In the words of Jack Snyder,

The wars of the French Revolution (1792-1802) and the Napoleonic Wars (1803-1815) revealed for the first time in history the full potential of belligerent mass nationalism (2000 p.154).

Among other scholars, Cederman, Sornette, and Warren (2011) present the most recent argument in this vein. They emphasize nationalism as an essentially exogenous force. Posen (1993) in contrast suggests that nationalism emerged endogenously as states in competition needed to motivate their populations. However, he shares the same emphasis on the French Revolution as a break point. According to this account, the critical turning point occurred during 1793 when the French revolutionaries first declared a levée en masse, applying the idea that anyone could be obliged to serve in order to defend France against encroaching armies. What is less often recognized by many scholars is that the levée en masse was actually a one off policy adopted during a period of particularly acute danger from invasion. Moreover, while it is clear that revolutionaries in Paris spoke of the importance of the nation in their public speeches, those careful studies that exist of the levée en masse at the local level do not reflect the same

\footnotetext{
${ }^{17}$ An idea most directly associated with North and Weingast (1989).
} 
degree of patriotic fervor. ${ }^{18}$ Finally, contrary to what is sometimes presumed, Napoleon actually abandoned the levée en masse as a method of recruitment. He instead used a more traditional system of conscription in which the wealthy could purchase a replacement. ${ }^{19}$

The idea that the French Revolution was a structural break provides one feasible, although certainly imperfect, way of examining the nationalism hypothesis. We can do so first of all by looking at all of the powers in our sample and examining whether both army sizes and levels of mobilization noticeably increased after 1789, and if so by how much. The idea here would be that while France pioneered the use of nationalism, other European powers were soon obliged to follow suit. For example, Linda Colley (1994) has argued that the wars of the revolutionary and Napoleonic period saw a new sense of nation appear in Great Britain. William McNeil (1982), among others, argues that nationalistic fervor played an important role in Prussia's rearmament in 1813-1814. A second way of examining the nationalism hypothesis is to examine the partial correlations between an indicator of nationalism and our dependent variables. Darden (forthcoming) argues that modern states find it difficult to instill national loyalties until the introduction of mass schooling. It takes a literate population educated by the state for countries to develop strong nationalist identities that influence political behavior. We investigate this hypothesis by using literacy rates as a proxy for nationalism. ${ }^{20} \mathrm{~A}$ third way in which we can examine the nationalism hypothesis is to look at a time series for France alone to examine to what extent the French Revolution appears as a structural break in the data on army sizes and mobilization ratios.

If we fail to find evidence that nationalism influenced army sizes or mobilization ratios, we will still want to consider the possibility of an interaction effect between the nationalism hypothesis and our own. It may have been the case that nationalism constituted a powerful force for motivating citizens, but until the invention of the railroad there was a technologically imposed ceiling on the size of an army that could actually be fielded and supplied. It may have been the case, as suggested by J.F.C. Fuller (1998) with reference to the railroad's inventor

\footnotetext{
${ }^{18}$ See Gagniage (1996) for an excellent example.

${ }^{19}$ Pigeard (2003) provides the most authoritative recent study on conscription during the Napoleonic era.

${ }^{20}$ Alternatively, any observed partial correlation between literacy and military size or mobilization may indicate state investments in education and the military to respond to security threats (Aghion, Persson, and Rouzet 2012).
} 
"Thus it came about that the genius of George Stephenson (1781-1848) gave life to the Clausewitzian theory of the nation in arms." 21

\section{War Mobilization in Great Power States, 1600-2000}

\subsection{Army Size and Mobilization Levels}

To assess what factors determine the scale of warfare and the extent of citizen participation in war, we have constructed a data set recording the size of the military and the extent of population mobilization for great power states from 1600 to 2000. We adopt Levy's (1983) definition of a great power as "a state that plays a major role in international politics with respect to securityrelated issues" (p. 16), and we adopt his coding of great powers. Levy identifies thirteen states that were great powers during some portion of the 1600 to 2000 period.

The key variable in the data set is Military Size which is defined as troops under the command of the national government and intended for use against foreign adversaries. It is measured in thousands. This definition does not include reserve troops, colonial troops, civil defense units, and domestic police forces. A common problem with statistics on the size of the military is that states have an incentive to inflate them. We made efforts to use numbers that reflect "actual" or "effective" forces rather than "paper" forces wherever possible. The appendix of this paper provides a complete discussion of the sources that we used to construct our data as well as full citations for these sources.

Military Size measures the absolute magnitude of great power forces. We are also interested in the extent to which citizens in these countries are mobilized for war, and so we have constructed the variable Military Mobilization, equal to military size divided by total population, to measure citizen participation. In addition to the distinction between "actual" and "paper" forces, it is important to keep in mind variation over time and across countries in the extent of the use of foreign troops. Ideally, our data for this measure would clearly separate domestic

\footnotetext{
${ }^{21}$ The three alternative factors discussed here do not, of course, exhaust the potential factors influencing military mobilization. Fertility rates and demography trends are also likely to matter and our analysis will control for population size. Other factors which may influence military mobilization but are difficult to measure directly include differences in the stakes and scope of various conflicts and improvements in food preservation and disease prevention. Our analysis will use a number of alternative strategies to limit potential bias due to these and other unobserved factors.
} 
Mobilization in Great Powers, 1600-2000

Military Size and Mobilization Rates
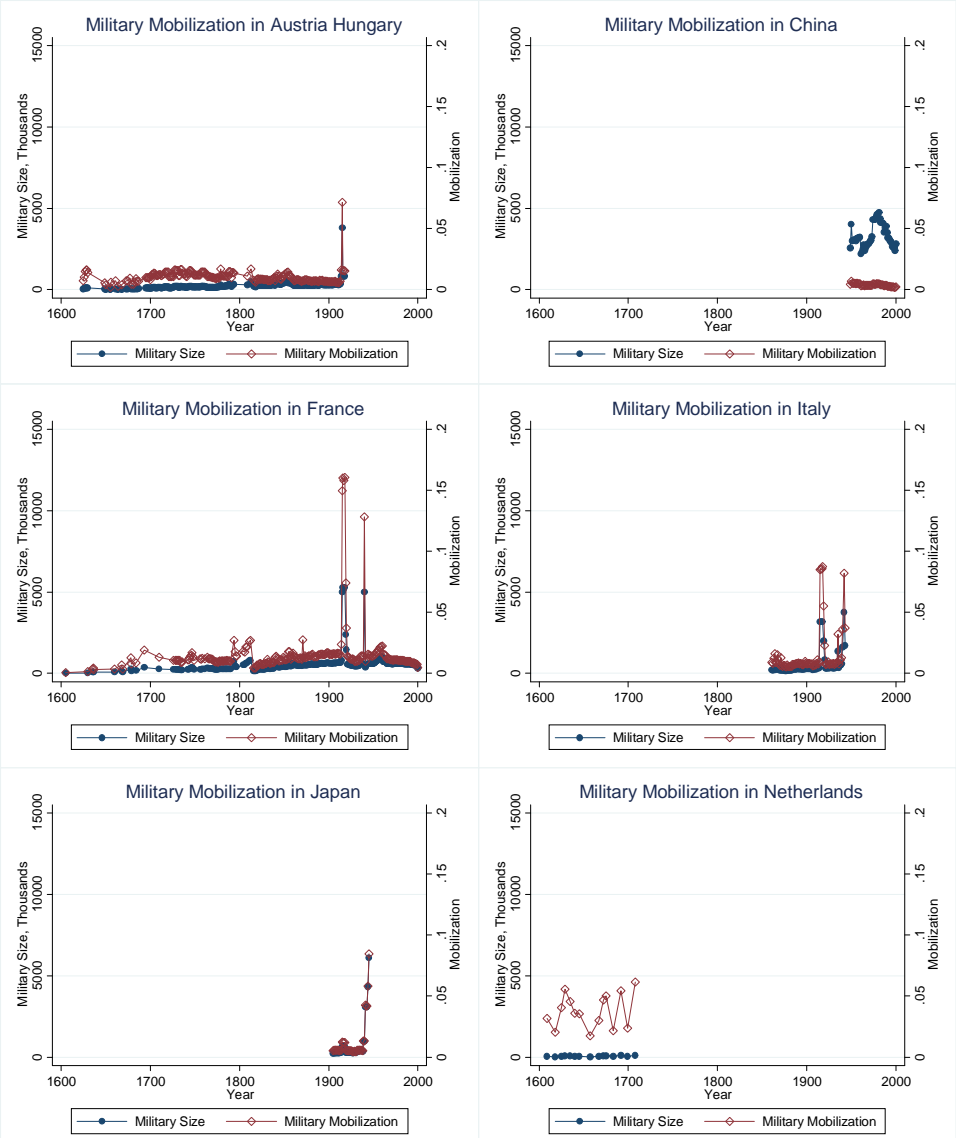

Figure 1: Mobilization in Great Powers, 1600-2000, Panel A. See text and appendix for sources.

and foreign troops. While we have a good deal of information about the recruitment patterns of each state and will discuss these in the next subsection, it is not possible to separate out foreign troops for the full data set. Instead, we will be careful throughout the paper to consider how the presence of foreign troops may influence our interpretation of the main factors determining variation in the size of military forces and the extent of mobilization.

Figures 1 and 2 present our data for Military Size and Military Mobilization for each of the thirteen sample countries during the years for which they were great powers. For each country, the plot with filled-in circles records the overall size of the military in thousands (left y-axis) and the plot with hollowed diamonds records mobilization levels (right y-axis). In interpreting 


\section{Mobilization in Great Powers, 1600-2000}

Military Size and Mobilization Rates
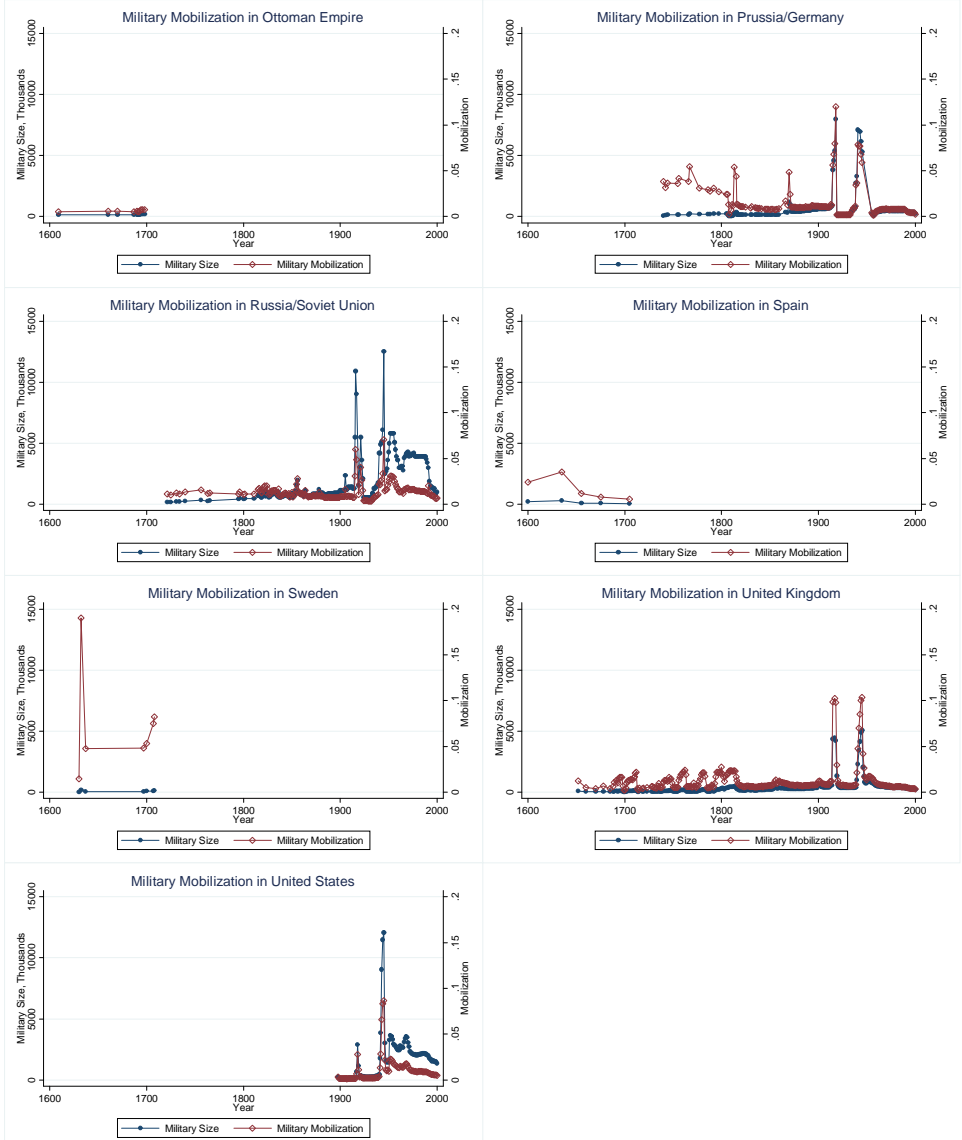

Figure 2: Mobilization in Great Powers, 1600-2000, Panel B. See text and appendix for sources. 
these graphs, it is important to keep in mind a few basic patterns in the data. First, annual data is generally available only for observations after the resolution of the Napoleonic Wars in 1815. Secondly, the incidence of war is greater in earlier periods than later periods. ${ }^{22}$ Third, these two facts interact in that data on war mobilization in the 17th and 18th centuries are more likely to be observed in war years. Given these patterns, as well as our substantive interest in war mobilization as opposed to the size of peacetime armies, in our statistical tests, we will focus our attention on the patterns of military size and mobilization during years in which these states are engaged in conflicts.

Table 1 reports descriptive statistics for Military Size and Military Mobilization for war years by century. The table along with Figures 1 and 2 highlights the most striking feature of our data: mass mobilized warfare reached an entirely new scale in the first half of the 20th century. The average for military size almost doubles from the 17th to the 18th century, it almost triples from the 18th to the 19th century, and then increases by a factor of 5.7 from the 19th to the 20th century. The averages for Military Mobilization are perhaps even more striking in highlighting the uniqueness of the 20 th century. The 17 th, 18 th, and 19 th century average mobilization levels are not that different from each other but average mobilization doubles from 0.017 in the 19th century to 0.034 in the 20th century. Figures 1 and 2 suggest that unsurprisingly these patterns are primarily driven by World War I and World War II. Although one might be worried that these averages are driven by differences across centuries in the propensity to fight wars and do not reflect the main events of international politics, for military size, the maximum values of the variable increase at quite similar rates as the averages (increasing by a factor of $2.02,2.72$, and 6.25 across each century).

At first glance, the maximum values for military mobilization rates appear to follow a different pattern but this is not very informative because the key figure that is out of place is the maximum of 0.19 for Military Mobilization in the 17th century. This is the value for Sweden in 1632 and it is a true outlier for the century (the next closest value is 0.056). Further, as we discuss below, this value is inflated by the heavy use of foreign troops. That said, there is a clear pattern of high mobilization rates with relatively small armies for small states like Sweden

\footnotetext{
${ }^{22}$ Using data primarily from Levy (1983) and the Correlates of War (2010), we found that 65\%,60\%, 25\%, and $23 \%$ of great power years involve wars in the $17 \mathrm{th}, 18 \mathrm{th}, 19 \mathrm{th}$, and 20 th century respectively.
} 


\begin{tabular}{lccccc}
\hline \hline & & \multicolumn{5}{c}{ Standard } \\
& Observations & Mean & Deviation & Minimum & Maximum \\
\cline { 2 - 6 } 17th Century & 69 & 95.370 & 62.225 & 13.000 & 362.000 \\
Military Size & 69 & 0.018 & 0.025 & 0.002 & 0.190 \\
Military Mobilization & & & & & \\
& & & & & \\
18th Century & 152 & 179.559 & 102.351 & 12.725 & 732.474 \\
Military Size & 152 & 0.016 & 0.011 & 0.002 & 0.082 \\
Military Mobilization & & & & & \\
& & & & & \\
19th Century & 80 & 481.516 & 324.011 & 11.134 & 2000.000 \\
Military Size & 80 & 0.017 & 0.009 & 0.002 & 0.054 \\
Military Mobilization & & & & & \\
20th Century & 142 & 2762.583 & 2546.014 & 125.923 & 12500.000 \\
Military Size & 142 & 0.034 & 0.036 & 0.002 & 0.161 \\
Military Mobilization & & & & & \\
\hline \hline
\end{tabular}

Table 1: Military Size and Mobilization by Century (in thousands). This table reports descriptive statistics for Military Size and Military Mobilization for each in year in which a great power in our sample is at war.

and Netherlands in 17th century and even somewhat larger states such as Prussia in the middle of the 18th century. Nevertheless, in the data set overall, Sweden 1632 is the only point in the top twenty mobilization rates that is not from the twentieth century. This descriptive evidence is suggestive of a clear break in the size of military forces and the extent of citizen participation in the twentieth century, a pattern we will probe in much greater detail below.

\subsection{Recruitment Methods}

In order to better understand changes in the format of military force over time, it also makes sense to consider how armies were recruited. We argued above that the invention of the railroad helped lead to a shift towards universal conscription in which members of the middle classes would be expected to serve in great numbers. This is a hypothesis that we will test formally below, but first it is worth presenting the evidence in more descriptive fashion.

Using a variety of different sources, we have been able to provide a sketch of the evolution of recruitment practices over time across the thirteen great powers. Each country is considered 
only for the period in which it was classified as a great power following the classification by Levy (1983). The results of this exercise are presented in Table 2. In this table we code a country as having had a system of conscription if there was a system by which central authorities determined how many individuals would be obliged to serve, how many from each region or locality, and if central authorities also established a rule (most commonly a lottery) through which individuals would be chosen. Situations where central authorities implicitly or explicitly sanctioned the use of force by local recruiters but did not establish a procedure for selection do not count as conscription according to this rule. In Table 2 we also identify the date at which a system of conscription became universal. Since no system of conscription is ever truly universal, it is also worth detailing how we arrived at this classification. By universal here we are referring to a system in which there are no explicit exemptions for those owning property and no possibilities for purchasing a replacement. However, according to the definition we have adopted a system of universal conscription might still have exemptions for age and educational deferments.

What conclusions can we draw from the evidence in Table 2? A first observation is that conscription of the non-universal variant developed quite early in a number of states, and in fact well before the French Revolution. This would seem to go against the arguments of Sidgwick (1883) and Ross (1994) who propose a causal chain running from army size, to deadweight costs, to choice of recruitment regime, unless of course the tax mechanisms used by earlier states were much more distortionary. At an earliest stage of development, recruitment tended to be decentralized and ad hoc, potentially reflecting weak central state capacity. Central authorities would give either army captains or local authorities the responsibility for recruiting a set number of individuals within a specific region. Army captains or local authorities then had considerable discretion in deciding what types of individuals would be recruited and what conditions would be offered in exchange for service. Over time, a number of states shifted toward a system of conscription in which a set number of individuals from each region had an obligation to serve, and central authorities specified the rule according to which individuals would be chosen. This was the case with the French system of militia recruitment from a very early date.

A second observation is that with the notable exception of Prussia, it was not until late into the nineteenth century, a period corresponding to the first military uses of the railroad, that one 


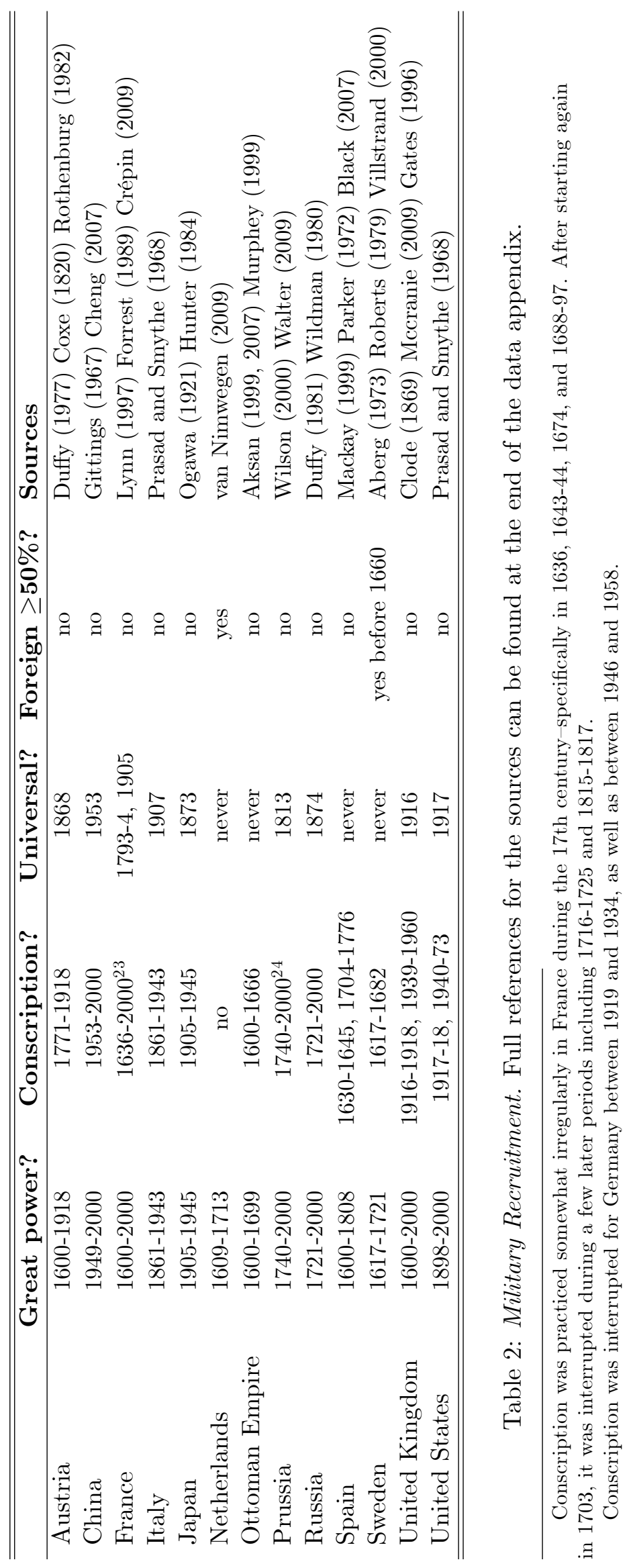


can begin to speak of the emergence of truly universal conscription in Europe. This suggests that the causal chain may in fact run from the introduction of the railroad, to an increase in army size, and thus an incentive to make conscription universal. It is generally known that European powers initially adopted conscription systems that provided the middle classes and the rich with substantial opportunities to escape service thanks to exemptions, opt-outs, or possibilities for purchasing a replacement. Even in those European cases that are sometimes offered as early examples of "universal" systems of conscription, actual practice until well into the nineteenth century involved substantial opportunities for the middle classes and the wealthy to avoid service. In France the levée en masse of 1793 was indeed an instance where those with wealth had few opportunities to avoid service. ${ }^{25}$ However, this was also a very brief episode. After Thermidor and Napoleon's subsequent assumption of power, France returned to a system of conscription in which those with wealth could avoid service by purchasing replacements. ${ }^{26}$ During the course of the nineteenth century the legal opportunities for avoiding service evolved continuously, and as documented by Crépin (2009), as late as 1905 conscription laws in France continued to offer certain social groups the opportunity of avoiding service. Prussia is often offered as another case of an early shift to universal conscription beginning in 1813, and we have used this date in Table $2 .^{27}$

In addition to drawing conclusions about how soldiers were recruited, the sources listed in Table 2 also provide us with useful information addressing the second question referred to above - who was recruited? It seems fair to say that it was not until the late nineteenth century that one can speak of the development of mass armies in which members of the middle and even upper classes served alongside peasants and the urban poor. During the era of voluntary and decentralized recruitment regimes, the most common pattern was for recruiting agents to focus on individuals who were in sufficiently difficult economic circumstances that even a very poorly paid position in the army might be voluntarily chosen. Subsequent compliance was then ensured by implementing extremely severe punishments for shirking or desertion. Another key

\footnotetext{
${ }^{25}$ See Gagniage (1996) as well as Bertaud (1988).

${ }^{26}$ The most authoritative account of the system of replacement in France can be found in Schnapper (1968). This practice was abolished in 1872 .

${ }^{27}$ With this said, it should be noted that Walter (2009) concludes that even after this date there remained very substantial opportunities for middle and upper income groups to avoid service.
} 
feature of this era was that several states made extensive use of foreigners serving in their army. This was the case for Spain's Army of Flanders during its long campaign against the Dutch Republic. $^{28}$ It was also the case for the army of the Dutch Republic during this period as well as for Sweden's army during the Thirty Years War. ${ }^{29}$ In fact, provided that they had access to the necessary finance, recruitment of foreigners provided states that had small populations, such as Sweden and the Netherlands, with a means of recruiting armies of the same size as those fielded by states with much larger populations.

The evidence in Table 2 supports the core argument of this paper. Rather than the invention of the idea of universal conscription and "the nation in arms" directly leading to the development of mass armies, the evidence in Table 2 is more consistent with our alternative interpretation. It was not until the invention and perfection of railroad transport that it became feasible and desirable to mobilize a truly mass army. Once this technologically driven transformation occurred, states faced incentives to develop systems of universal military conscription.

\section{Evaluating Explanations for Patterns of War Mobilization}

The data presented in Section 4 on military size and mobilization indicate significant variation in the format of military force adopted by great power states. In this section, we propose a series of empirical investigations using this data in order to evaluate our argument that the introduction of new transport and communication technologies has been the major factor determining the use of mass armies. We also discuss the evidence in light of the main alternative explanations emphasized in the literature. ${ }^{30}$

\footnotetext{
${ }^{28}$ See the detailed evidence provided by Parker (1972).

${ }^{29}$ van Nimwegen (2009) cites evidence suggesting that half of Dutch forces were foreigners. Roberts (1979) estimates that in several key battles toward the end of the Thirty Years War, over four fifths of the forces under Swedish command were foreign.

${ }^{30}$ Although not focused on the role of transport and communication technologies, Thompson and Rasler (1999) investigate the correlates of army size over a similarly long time period. They combine years of peace and years of war and find unsurprisingly that army sizes are larger in times of significant wars. They consider technological military revolutions generally, but they do not measure them directly and conflate those that are likely to increase and decrease army size. Our analysis is specifically focused on the question of what accounts for variation in military size and mobilization during times of war.
} 


\subsection{Military Size and Mobilization - An Indirect Test}

We start our investigation of the pooled data by examining whether key dates associated with various arguments are correlated with changes in levels of military size and the extent of mobilization, recognizing of course that other factors may have changed at the same time.

First, we investigate whether two key dates associated with innovations in transport and communication technology are significantly correlated with changes in observed levels of mobilization. For railways, we set the date at 1859, the year proposed by Pratt (1915) in which railways were first used in a significant way in military conflict. This date corresponds quite closely with the introduction of the Pullman sleeping car, which occurred in 1857 . While troops at this time certainly traveled in considerably less luxurious conditions than Pullman sleepers, this is nonetheless a good indication that railway technology was undergoing a very rapid advance. There are a number of plausible alternative dates for innovations which dramatically improved the remote delivery of explosive force. One possibility is to focus on the role of precision-guided weapons. For this innovation, we set the date at 1970 to correspond to the development of modern cruise missiles. Although the United States developed an early version of a cruise missile in 1954 and the USSR did so in $1956,{ }^{31}$ it was not until the late 1960s that fully operational and effective cruise missiles were a viable option to military planners. ${ }^{32}$ We also considered focusing on the role of intercontinental ballistic missiles (ICBM) in expanding the remote delivery of explosive force. The first operational ICBM was in 1957, and the results discussed below are quite similar using this date rather than 1970.

As a second test, we look for evidence that the French Revolution was a structural break consistent with the nationalism hypothesis by examining whether army size and levels of mobilization noticeably increased after 1789 , and if so by how much. ${ }^{33}$

\footnotetext{
${ }^{31}$ An early U.S. cruise missile was the TM-61 Matador (Huisken 1981, p.167) and an early USSR cruise missile was the SSC-2 Kennel (Huisken 1981, p.98).

${ }^{32}$ See Werrell (1985 ch.5) for a discussion of advances in cruise missile guidance systems and the plausibility of 1970 as a break date. It is also worth noting that this date corresponds quite closely to the first operational use of a laser guided bomb, which was by the United States in 1968. See Hallion (1995) for a discussion of the development of precision guided bombs and the way in which the invention of the laser guided bomb fundamentally changed the nature of aerial bombardment.

${ }^{33}$ It is interesting to note that whether for English, French, or German language texts, Google Ngrams data show a structural break upwards in the late eighteenth century for the frequency of use of the word "nation." Moreover, in all three languages frequency of appearance of this word declined after this point.
} 
To test for these hypothesized breaks, we constructed three indicator variables, D1789, $D 1859$, and $D 1970$, equal to 0 for all years before the year indicated and equal to 1 thereafter. The sample is all 443 country years for which we have data on military size and a great power country is at war. In evaluating these break points, it is essential that we take into account fixed unobserved factors for each state. Great powers differ in important ways that may influence their propensity to raise a large army or to mobilize a significant proportion of their population. Some of these differences are relatively fixed, having to do with the historical origins of the state's formation or its salient geographic features. To control for these determinants, we include country fixed effects. Note further that our initial analysis conditions on countries being in the sample of great powers. We are investigating the correlates of military size and mobilization given that a country is a great power. To the extent that great power status is determined by unobservables correlated with these break points or other variables of interest, the results will not give good estimates of the correlates of military size and mobilization for all types of countries. That said, some of our analyses will control for the most obvious measures determining great power status, such as size and wealth, and we will present additional results from a larger sample of countries. Moreover, we are primarily interested in the question of the size of the military for the central states of the international system. Our initial evaluation of the role of these potential structural breaks is simply fixed effects regressions with Military Size and Military Mobilization as the dependent variables and the three indicator variables as the only independent variables.

The results for these regressions are reported in column 1 of Tables 3 and 4 . Table 3 provides the estimates for Military Size and Table 4 reports results for Military Mobilization. Starting with Table 3, the coefficient estimate for D1789 is -23.930 with a standard error, adjusted for clustering by country, of $138.442 .{ }^{34}$ This indicates that there is no substantively or statistically significant difference between the size of armies in war time before and after 1789 . The estimate for D1789 in Table 4 with Military Mobilization as the dependent variable is also small and statistically insignificant. There is little evidence associated with a structural break

\footnotetext{
${ }^{34}$ Because the number of clusters in our sample is relatively small, we reestimated all the specifications reported in Tables 3 and 4 with robust standard errors that were not clustered on country. The clustered standard errors were generally larger though the substantive results without clustering were consistent with the findings with clustered standard errors reported in the tables.
} 
in the adoption of larger armies at the time of the French Revolution or Napoleonic Wars. This may be inconsistent with the nationalism hypothesis and reflect the fact that European powers had already mobilized relatively large armies for major conflicts such as the War of Austrian Succession throughout the 18th century. Alternatively, it may indicate that only France was able to successfully construct a nationalist ideology conducive to raising significantly larger armies than in previous periods. We evaluate the French case in greater detail in the next section. Finally, this test is indirect and it may be that as conservatives took power after the resolution of the Napoleonic Wars that nationalism was no longer employed to mobilize troops and so the coefficient for $D 1789$ is not a good indicator of the impact of nationalism. We present a more direct test below.

Turning to the potential break point for the influence of railroads, the coefficient estimate in column 1 of Table 3 for D1859 is 2,031 with a standard error of 545. This estimate suggests that the great powers fielded armies which were on average 2 million men larger after 1859. Similarly the estimate in column 1 of Table 4 for D1859 is 0.021 with a standard error of 0.004 . This indicates that population mobilization was a full two percentage points higher on average during this period. To put this in context, Table 1 indicates that the average mobilization level for the 18th century was 0.016 and so a 0.021 difference is a more than doubling of mobilization rates. These estimates clearly suggest an important structural break in military size and mobilization, the timing of which coincides with major expansion of the railroads and the adoption of rail transport for moving troops and military supplies.

Finally, the coefficient estimates for D1970 in column 1 of both Table 3 and Table 4 are negative and substantively and statistically significant. The estimate in the Military Mobilization regression is comparable in magnitude to that for D1859 and the estimate for Military Size is also quite large. This suggests that the extent of mobilization after 1970 returned to levels that looked quite similar to those before 1859. This is consistent with the hypothesized negative effect of precision weapons. This evidence, however, should be interpreted cautiously because in addition to it being simply based on the timing of mobilization changes, there are a limited number of wars involving great powers after 1970. Nevertheless, the descriptive evidence for both Military Size and Military Mobilization is broadly consistent with our argument that the 
most substantial innovations in the use of mass warfare were made possible by critical changes in transport and communications technology. ${ }^{35}$

\subsection{Military Size and Mobilization - A Direct Test}

The evidence that we have presented so far is essentially indirect. To more directly test the importance of transport technology, we constructed the variable Railroad Track equal to the length of railroad track available to the public in each country. ${ }^{36}$ Ideally we might prefer a measure that would indicate in a precise manner how both the extent and organization of a nation's railway network increased the maximum army size that could be sustained, by facilitating movement of men as well as the goods to keep them supplied. However, even if such information was readily available for all of our sample countries, it is likely that including it would introduce a degree of bias into our estimates. Why would this be the case? We know from the extensive work by Bogart (2009) that governments subject to external military threats tended to increase central state control and ownership of railway networks. However, he shows, based on an extensive cross-country sample for the period between 1860 and 1912, that governments which nationalized their railways actually subsequently tended to construct fewer new kilometers of railway than was the case for states in which the rail network remained in private hands. We also know from Bogart's data that the great majority of rail networks during this period

\footnotetext{
${ }^{35}$ An alternative approach to this indirect test would be to use our time series data for each individual great power to estimate structural breakpoints using Bai and Perron's (2003) methodology. Unfortunately, our data has two characteristics that make this approach problematic. First, there are gaps in our time series due to years of peace. Second, for most countries, the number of war years is a relatively small number of observations.

Although we think there could be separate processes at work in determining peace-time army size, one way to apply this approach is include all years in the analysis. The inclusion of peace years does not, however, solve all the problems associated with conducting a structural break test of our arguments. For an individual time series to be useful for this purpose, the country needs to be a great power continuously from the 18th century, prior to the French Revolution, to the late 20th century. Another issue is that despite having the most complete comparative data on military size for our time period, there is still missing data for some years prior to 1815 . This again creates gaps in the time series. Taking these two considerations into account, we were able to identify one country for which we had a continuous time series over the relevant periods - the United Kingdom for 1728-2000.

For this case, we implement Bai and Perron's (2003) algorithm for estimating optimal break points for both Military Size and Military Mobilization. For both series, the minimum BIS segmentation suggests two break points and the years associated with these break points are 1914 and 1954. These dates are broadly consistent with main results of the indirect tests presented in this secton and the more general arguments of the paper.

${ }^{36}$ The original railroad track data is measured in kilometers but for Railroad Track we have divided this variable by one million-thus the units are millions of kilometers-so that the coefficients for both Military Size and Military Mobilization could be easily read. The sources for the railroad track data were Mitchell (2007a, 2007b, 2007c). A small number of observations for the railroad measure were linearly interpolated.
} 


\begin{tabular}{|c|c|c|c|c|}
\hline & \multicolumn{4}{|c|}{ Military Size } \\
\hline & \multicolumn{4}{|c|}{ OLS Estimates } \\
\hline & (1) & $(2)$ & (3) & $(4)$ \\
\hline \multirow[t]{3}{*}{ D1789 } & -23.930 & 96.674 & & \\
\hline & $(138.442)$ & $(83.746)$ & & \\
\hline & 0.866 & 0.271 & & \\
\hline \multirow[t]{3}{*}{$D 1859$} & 2030.983 & 219.159 & & \\
\hline & $(545.037)$ & $(477.470)$ & & \\
\hline & 0.003 & 0.654 & & \\
\hline \multirow[t]{3}{*}{ D1970 } & -1166.186 & 353.256 & & \\
\hline & $(448.374)$ & $(339.786)$ & & \\
\hline & 0.023 & 0.319 & & \\
\hline \multirow[t]{3}{*}{ Railroad Track } & & 43707.090 & 35002.650 & 31969.210 \\
\hline & & $(11831.450)$ & $(5297.878)$ & $(2588.817)$ \\
\hline & & 0.003 & 0.000 & 0.000 \\
\hline \multirow{3}{*}{ Cruise Missile } & & -427.278 & -3689.954 & -3264.737 \\
\hline & & $(271.825)$ & $(637.663)$ & $(1004.757)$ \\
\hline & & 0.142 & 0.000 & 0.007 \\
\hline \multirow[t]{3}{*}{ Population } & & & 0.013 & 0.023 \\
\hline & & & $(0.002)$ & $(0.016)$ \\
\hline & & & 0.000 & 0.184 \\
\hline \multirow{3}{*}{ GDP per capita } & & & 0.306 & 0.198 \\
\hline & & & $(0.129)$ & $(0.163)$ \\
\hline & & & 0.035 & 0.248 \\
\hline \multirow[t]{3}{*}{ Literacy Quartile } & & & -78.382 & -92.401 \\
\hline & & & $(110.424)$ & $(199.921)$ \\
\hline & & & 0.491 & 0.652 \\
\hline \multirow[t]{3}{*}{ Democracy } & & & -630.863 & -111.130 \\
\hline & & & $(540.274)$ & $(367.834)$ \\
\hline & & & 0.266 & 0.768 \\
\hline Country Fixed Effects & Yes & Yes & Yes & Yes \\
\hline Common Year Trend & No & No & Yes & No \\
\hline Country-specific Year Trend & No & No & No & Yes \\
\hline Number of Observations & 443 & 443 & 443 & 443 \\
\hline
\end{tabular}

Table 3: Military Size in Great Power Wars, 1600-2000. The table reports the results of pooled-time-series-cross-sectional OLS regressions for the variable Military Size. The table reports the coefficient estimate, robust standard error clustered on country (in parentheses), and corresponding p-value. 


\begin{tabular}{|c|c|c|c|c|}
\hline & \multicolumn{4}{|c|}{ Military Mobilization } \\
\hline & \multicolumn{4}{|c|}{ OLS Estimates } \\
\hline & (1) & $(2)$ & (3) & (4) \\
\hline \multirow[t]{3}{*}{$D 1789$} & 0.003 & 0.003 & & \\
\hline & $(0.002)$ & $(0.002)$ & & \\
\hline & 0.263 & 0.135 & & \\
\hline \multirow[t]{3}{*}{$D 1859$} & 0.021 & 0.012 & & \\
\hline & $(0.004)$ & $(0.004)$ & & \\
\hline & 0.000 & 0.012 & & \\
\hline \multirow[t]{3}{*}{ D1970 } & -0.020 & -0.003 & & \\
\hline & $(0.006)$ & $(0.004)$ & & \\
\hline & 0.006 & 0.546 & & \\
\hline \multirow[t]{3}{*}{ Railroad Track } & & 0.224 & 0.205 & 0.298 \\
\hline & & $(0.106)$ & $(0.075)$ & $(0.111)$ \\
\hline & & 0.056 & 0.018 & 0.020 \\
\hline \multirow[t]{3}{*}{ Cruise Missile } & & -0.013 & -0.031 & -0.030 \\
\hline & & $(0.003)$ & $(0.009)$ & $(0.010)$ \\
\hline & & 0.000 & 0.005 & 0.009 \\
\hline \multirow[t]{3}{*}{ Population, Billions } & & & 0.035 & -0.102 \\
\hline & & & $(0.041)$ & $(0.267)$ \\
\hline & & & 0.409 & 0.709 \\
\hline \multirow[t]{3}{*}{ GDP per capita, Thousands } & & & 0.001 & 0.000 \\
\hline & & & $(0.001)$ & $(0.001)$ \\
\hline & & & 0.425 & 0.841 \\
\hline \multirow[t]{3}{*}{ Literacy Quartile } & & & 0.001 & 0.002 \\
\hline & & & $(0.003)$ & $(0.005)$ \\
\hline & & & 0.854 & 0.738 \\
\hline \multirow[t]{3}{*}{ Democracy } & & & 0.013 & 0.014 \\
\hline & & & $(0.005)$ & $(0.002)$ \\
\hline & & & 0.016 & 0.000 \\
\hline Country Fixed Effects & Yes & Yes & Yes & Yes \\
\hline Common Year Trend & No & No & Yes & No \\
\hline Country-specific Year Trend & No & No & No & Yes \\
\hline Number of Observations & 443 & 443 & 443 & 443 \\
\hline
\end{tabular}

Table 4: Military Mobilization in Great Power Wars, 1600-2000. The table reports the results of pooled-time-series-cross-sectional OLS regressions for the variable Military Mobilization.The table reports the coefficient estimate, robust standard error clustered on country (in parentheses), and corresponding p-value. 
remained privately owned. ${ }^{37}$ At a minimum, this evidence suggests that the coefficients on our Railroad Track measure will not be subject to an upward bias attributable to the anticipation of conflict. ${ }^{38}$ In unreported specifications, we find qualitatively similar results using a measure, Railroad Track Area, equal to railroad track kilometers divided by land area. ${ }^{39}$

In addition to our railroad track variable, to more directly test the importance of the expansion of the remote delivery of explosive force, we constructed the variable Cruise Missile which is equal to the 0 for each year before a country acquires a cruise missile and 1 for each year after acquisition. ${ }^{40}$ We also find qualitatively similar results using a measure indicating the acquisition of nuclear weapons and another variable measuring the estimated count of nuclear warheads. $^{41}$

Column 2 of Tables 3 and 4, reports the results for fixed effects regressions which are the exact same specification discussed for column 1 with the addition of the variables Railroad Track and Cruise Missile. It is worth noting that inclusion of country fixed effects will control for any fixed component of country size. Starting with Table 3, the coefficient estimate for Railroad Track is equal to 43,707 with a standard error of 11,831 which indicates that if a country increases it rail network by a thousand kilometers, it would on average increase the size of its army during war time by about forty-four thousand troops. The standard deviation of Railroad Track is about 79 thousand kilometers and so a standard deviation increase in the length of track is associated

\footnotetext{
${ }^{37}$ Across his sample, in $186093 \%$ of railway kilometers were privately held, $82 \%$ in 1880 , and $74 \%$ in 1900 . Bogart's sample includes Russia, Sweden, Denmark, the Netherlands, Belgium, France, Switzerland, Italy, Austria, Hungary, Bulgaria, Serbia, Japan, Mexico, Costa Rica, Brazil, Argentina, Germany, India Australia, and New Zealand.

${ }^{38}$ We should also note that Donaldson (2010) makes the exact opposite assumption from us in order to propose a means of estimating the causal impact of railway construction on economic development. He suggests that since railroads in India were built principally for military/strategic reasons, they can be treated as exogenous for his purposes. However, it should be noted that the railway network in India was entirely government owned and operated, a very different situation from that which existed in Europe. Therefore, his identifying assumption can be plausible at the same time that we make the exact opposite assumption for a different set of countries.

${ }^{39}$ More specifically, the coefficient estimates are all positive as hypothesized. For the mobilization dependent variable, the estimates are statistically signficant across specifications, but for the military size dependent variable, they are less precisely estimated and not statistically signficant in all specifcations.

${ }^{40}$ For China, France, and Germany, the main source for this data is National Defense Industrial Association (1999). For the USSR and USA, the main source is Huisken (1981). We also consulted various years of the journal Military Balance for these two cases. For the UK, the sources are International Institute for Strategic Studies (1974) and the National Defense Industrial Association (1999). The other great power states were not great powers during the period of cruise missile development.

${ }^{41}$ The source for our variable measuring nuclear capability is Singh and Way (2004). The source for the estimated nuclear warhead measure is: "Table of Nuclear Weapons Stockpiles, 1945-2002." Natural Resource Defense Council. URL: http://www.nrdc.org/nuclear/nudb/datab19.asp Accessed on 11 January 2012.
} 
with an increase in troop size of over 3 million troops. This estimate is consistent with our claim that railroads played a decisive role in the transition to truly mass armies that numbered in the millions. Importantly, once Railroad Track is included in the regression, the estimate for D1859 is much smaller and no longer statistically significant. This is consistent with the idea that the likely reason for the structural break in the series for 1859 was the increasing use of railroads in warfare. The estimates in column 2 of Table 4 indicate a qualitatively similar story for Military

\section{Mobilization.}

The coefficient estimates for Cruise Missile are negative in column 2 of Tables 3 and 4 which is consistent with the hypothesis that the capacity to deliver explosive force remotely made large armies less desirable. Importantly, it is also the case that the estimate for D1970 is substantially attenuated and no longer statistically significant. The coefficient estimate for Cruise Missile is only marginally statistically significant for Military Size, but the estimate for Military Mobilization is equal to -0.013 with a standard error of 0.003 . This result suggests that great powers mobilized over one percent less of their populations after developing cruise missiles. Obviously, it is not likely that this full difference is solely attributable to the impact of cruise missiles as these states were developing a wide range of weapons that expanded their ability to deliver force at a distance - including nuclear weapons. Nonetheless, it is clear that the timing of these innovations is associated with a significant reduction in army size and mobilization.

The estimates in columns 3 and 4 in Tables 3 and 4 explore the robustness of these estimates by adding additional control variables to the specifications in columns 2 and 3. Our discussion of alternative arguments about the determinants of army size and the extent of population mobilization emphasized three other factors.

First, countries with greater fiscal capacity in terms of wealth and efficient institutions for taxation, are, all else equal, more likely to field large armies. We constructed the variable GDP per capita as one proxy for a state's fiscal capacity. ${ }^{42}$ In unreported specifications, we also used a dummy variable Census recording whether a state had carried out a national census to more

\footnotetext{
${ }^{42}$ The source for this variable for all countries except the Ottoman Empire was Maddison (2003). The data were accessed online at http://www.ggdc.net/MADDISON/oriindex.htm. For the Ottoman Empire, we used estimates from personal communication with Sevket Pamuk (see also Pamuk 2009). Missing data was linearly interpolated for this variable. The variable used in Table 3 is in 1990 international G-K dollars. The variable is rescaled to thousands of 1990 international G-K dollars in Table 4.
} 
directly proxy for administrative capacity. ${ }^{43}$

Second, states may find it easier to raise large armies if they have extended substantial political rights to citizens. To explore this argument we first constructed the variable Democracy, set equal to one if the legislature is elected in free multi-party elections, if the executive is directly or indirectly elected in popular elections and is responsible either directly to voters or to a legislature elected according to the first condition, and finally if at least 50 percent of adult males have the right to vote. ${ }^{44}$ In unreported specifications we also included two variables concerning prerogatives of representative assemblies. The dummy variable Taxes takes a value of 1 if a state has a representative assembly that has the authority to consent to or refuse new taxation. The dummy variable Spending takes a value of 1 if a state has a representative assembly with the authority to exert control over expenditure decisions. ${ }^{45}$

Third, building on the idea that states find it difficult to instill national loyalties until the introduction of mass schooling, we use literacy rates as a proxy for nationalism. The variable Literacy Quartile is coded from 1 to 4 indicating what quartile of the adult population can read. ${ }^{46}$ In addition to the above controls, we also add a control for the size of a country's total

\footnotetext{
${ }^{43}$ The sources for this variable are as follows. Austria-Hungary (Encyclopedia Britannica 1911 edition), China (Orleans, 1957), France (Insee, "Le recensement de la population dans l'histoire", Italy (Encyclopedia Britannica 1911 Edition), Japan (Eng and Smith, 1976), Netherlands (Oomens and den Bakker, 1997), Ottoman Empire (Karpat, 1978), Prussia, Russia, Spain (Encylopedia Britannica 1911 Edition), Sweden (Hendricks, 1861), UK (Taylor, 1951), United States (US Bureau of the Census). We report the results using GDP per capita to measure state capacity simply because the results for the census measure were generally quite weak.

${ }^{44}$ This follows the definition used by Boix and Rosato (2001), which is a modification of the definition used by Przeworski et al. (2000) to a context where the suffrage may be restricted.

${ }^{45}$ The principal source for both of these variables is Stasavage (2010, 2011).

${ }^{46}$ The coding and sources for this variable are as follows: Austria-Hungary is coded a 1 for 1600-1749 and 2 for 1750-1849. It is coded a 3 for 1850-1888 and 4 for 1889-1918 based on Cipolla (1969). China is coded 1 for 1949-1963, 2 for 1964-1981, 3 for 1982-1989, and 4 for 1990-2000. Data for 1950 and 1958 in Ross (2005); data for 1964 in Dreze and Toh (1995); and data for 1982, 1990, and 2000 from UESCO, http://ddp-ext.worldbank.org/EdStats/CHNgmrpro05b.pdf (Accessed January 2012). France is coded 1 for 1600-1749, 2 for 1750-1849, 3 for 1850-1888, and 4 for 1889-2000. For 1800 to 2000, the source for the French data is Mironov (1991). The transition point for adult literacy in 1749 is based on a $35 \%$ literacy rate for males and the fact that the difference between male and female literacy rates later in the century is about 8-10 percentage points. The source for the male literacy data is Stone (1969). Prussia/Germany is coded 2 for 1740-1799 based on data from the UK, 3 for 1800-1849, and 4 for 1850-2000. The source for 1800 to 2000 is Mironov (1991). Italy is coded 1 for 1861-1869, 2 for 1870-1899, 3 for 1900-1929, and 4 for 1930-1943. The source for this data is Tortella (1994). Japan is coded a 4 for 1905-1945. The source is Mironov (1991) and is based on male-only data. The Ottoman Empire is coded as a 1 for 1600-1699. Literacy in the Ottoman Empire was in the single digits in 1820 and 1870 (Pamuk, Sevket, and van Zanden 2010) and we based our coding on this fact. The Netherlands is coded 3 for 1609 to 1713 and the source is Graff (1987). Russia/Soviet Union is coded 1 for 1721-1896, 2 for 1897-1925, 3 for 1926-1938, and 4 for 1939-2000 and the source is Mironov (1991). Spain is coded a 1 for 1600-1808. Literacy was in the first quartile in 1820 and 1870 (Pamuk, Sevket, and van Zanden 2010) and we based our coding on this fact. Sweden is coded a 1 for $1617-1660,2$ for $1661-1685,3$ for $1686-1710$, and 4 for $1711-1721$. These estimates are based on Johansson (2009). The United States is coded a 4 for 1898-2000 and the source is the National
} 
population. Finally, these specifications include either a common or country-specific linear year trend.

The results reported in columns 3 and 4 of Table 3 show that the addition of control variables results in relatively little change in our estimates of the coefficient for Railroad Track. In contrast, the addition of controls does result in a substantial change in the estimated coefficients for our Cruise Missile variable. In both columns 3 and 4 the coefficient on Cruise Missile is now statistically significant, negative, and also much larger than in the specifications without the controls. We drew very similar conclusions about our key variables of interest in our unreported specifications that added the Census, Taxes, and Spending variables to the specification.

The results reported in columns 3 and 4 of Table 4 , which reflect the addition of control variables to our mobilization regressions, show a very similar pattern to that observed in the previous table. The addition of the control variables has little impact on our coefficient estimates for Railroad Track. However, the addition of the control variables results in a substantially larger negative coefficient for our Cruise Missile variable. Once again, we drew very similar conclusions in unreported specifications that used alternative measures for our key independent variablesRailroad Track Area for railroad development and nuclear weapons or nuclear warhead counts for the expansion of the remote delivery of explosive force - and alternative measures of our control variables-Census, Taxes, and Spending.

The estimates for the control variables are somewhat sensitive to specification choices. For example, in Table 3, Population and GDP per capita are positive and statistical significant in the specification with common year trend but not in the specification with country-specific trends. Two results for the control variables stand out.

First, there is no evidence of a positive partial correlation between Literacy Quartile and either dependent variable. This complements our evidence on the lack of a break point in either series near 1789 and is consistent with our claim that nationalism may not have played as central role in bringing about the era of mass warfare as is often argued. That said, we pursued another possibility that is complementary to our emphasis on transportation and communication

Center for Education Statistics (1993). The United Kingdom is coded 1 for 1600-1674, 2 for 1675-1799, 3 for 1800-1869, and 4 for 1870-2000. The transition date of 1674 is based on a $45 \%$ literacy rate for males (Stone 1969 ) and the fact that the difference between adult and male literacy rates in the 17th century were around 10 percentage points. The remainder of the series is based on data from Mironov (1991) and Tortella (1994). 
technologies. It may be the case that nationalism played a role in making citizens willing to fight but that until the railroad and other technologies allowed mass armies to be supplied, nationalism only had a limited effect. To operationalize this idea, we added an interaction term for Railroad Track and Literacy Quartile to the specifications in cols 3 and 4 of Tables 3 and 4 with the expectation that the coefficient for this interaction would be positive. Our estimates for this interaction coefficient were positive in all four specifications and statistically significant in all cases except for the specification with Military Mobilization as the dependent variable and country-specific time trends. This suggests that once railroad penetration was high, nationalism, as measured by literacy rates, had a more positive effect on mobilization. ${ }^{47}$ We further calculated the marginal effect of literacy at different values of railroad development and found that at high levels of railroad development literacy has a positive and statistically significant marginal effect on Military Size and Military Mobilization. Such an effect is consistent with our argument that although various factors such as nationalism may make it easier for states to recruit large armies, it is only once railroad technologies are sufficiently developed to supply such armies that the era of the mass army begins. ${ }^{48}$

Second, we find some evidence that expanding political rights facilitates mobilizing populations for war. Our democracy variable is not correlated with Military Size but is positively correlated with Military Mobilization. Moreover, in unreported specifications, we find some evidence that both our Taxes and Spending variables are positively correlated with Military Size and Military Mobilization. ${ }^{49}$

\footnotetext{
${ }^{47}$ Alternatively, it may indicate simply that states invested more in education in order to field effective mass armies (Aghion, Persson, and Rouzet 2012).

${ }^{48}$ As suggested previously, an alternative measure of nationalism is the based on the relative frequency of the use of the word "nation" using Google Ngrams data. We constructed this measure for France, Germany, and the United Kingdom. With the caveat that we only have data for three countries, a few interesting patterns emerge. First, the bivariate correlation coefficients between the Ngram measure and the mobilization measures are positive but of modest magnitude for France and the United Kingdom and positive and of substantial magnitude for Germany (France: 0.095 for Military Size and 0.099 for Military Mobilization; Prussia/Germany: 0.587 and 0.344; United Kingdom: 0.080 and 0.183). Second, if one substitutes the Ngram measure for Literacy Quartile in the three countries for which the former measure is available, the coefficient estimate for the Ngram measure of nationalism is positive and, in some specifications, statistically significant. Our interpretation of these mixed results is that it seems possible that nationalism has played some role in determining mobilization, but the evidence is not particularly strong. Moreover, the overall pattern of our the findings indicate that to the extent nationalism did have an effect, that role came later than is usually asserted.

${ }^{49}$ In general, these results were strongest for specifications with Military Mobilization as the dependent variable and with a common year trend. We also investigated the possibility of an interaction between democracy and our railroad measure, but we found little evidence consistent with the hypothesis.
} 
Our discussion of the results so far has included mention of a number of robustness checks that focus on alternative measures of our independent variables. We also explored the robustness of the results in a number of other ways. First, we reestimated our main specifications for Military Size in log-levels. This specification may be less sensitive to potential outlier observations. Our main estimates for railroad Railroad Track and Cruise Missile are qualitatively the same for these specifications. Second, we reestimated our main specifications for both dependent variables with year fixed effects. This specification has the advantage of controlling for common shocks, but given the small number of countries and conflicts in our data in any given year, we do not have a lot of data for this specification. We find that the Railroad Track estimate for Military Size is robust to this specification but not our other key coefficient estimates. Third, we added control variables for other technologies that may have played a role in allowing states to field larger armies. Specifically, we added controls for the number of telegrams and the number of steam and motor ships in a country in a given year. ${ }^{50}$ All of our main results are qualitatively similar in these specifications, and the estimates for these variables were mixed with the expected positive coefficient significant in some specifications. Fourth, we reestimated our regressions for alternative samples. We were concerned that cases with high numbers of foreign soldiers - the Netherlands, Spain, and Sweden prior to 1660 - might be driving our results, and so we dropped these from the analysis. We were also concerned that either World War I or the combination of World War I and World War II might be driving the results, and dropped these years as well. We also considered the possibility that Prussia/Germany and Russia/USSR were cases for which the potential endogeneity of railroad development might be of strongest concern, and so we dropped these countries individually and together. Our main findings are unchanged for analyses dropping the high foreign soldier cases or eliminating Prussia/Germany or Russia/USSR. ${ }^{51}$ Similarly, dropping World War I era conflicts from the analysis has no impact on the pattern of estimates. Dropping both World War I and World War II conflicts, however, is consequential. The coefficient estimates for Railroad Track are positive and generally statistically

\footnotetext{
${ }^{50}$ The source for this data is Comin and Hobijn (2009).

${ }^{51}$ The only partial exception to this pattern is that if both Prussia/Germany and Russia/USSR are dropped, the p-value for the railroad estimate drops to 0.14 and the p-value for the cruise missile coefficient drops to 0.233 in the regressions with Military Mobillization as the dependent variable, a full set of controls, and country-specific year trends.
} 
significant across specifications, ${ }^{52}$ but the partial correlations between Cruise Missile and our dependent variables disappear. Finally, we added a control variable for the extent of mobilization by neighboring great powers to account for the possibility that army size varied in reaction to the behavior of actual or potential enemies. The coefficients estimates for Railroad Track are positive and statistically significant across all of these specifications. The estimates for Cruise Missile are negative in all specifications with the caveat that the estimates are only marginally statistically significant in the Military Mobilization specifications. While it is the case that the neighbor mobilization measures are also significantly positively correlated with mobilization and that the inclusion of this variable somewhat attenuates the magnitude of our key coefficient estimates, it is not necessarily the case that this suggests a weaker role for the technology factors emphasized in this paper. States certainly react to each other but the higher (lower) mobilization rates that they are reacting to are in part chosen because of the very technological factors that we emphasize in this paper.

Another potential concern with our analysis is the process by which countries are selected into the great power sample might bias our estimates of the role of transport and communication technologies in determining the extent of military mobilization. To address this possibility, we conducted an alternative analysis for the period 1816-2000 including 60 different countries. ${ }^{53}$ We were able to estimate the same specifications for this sample as those featured in our main analysis with the exception of a measure for precision weapons. Table 5 reports the results for our main specifications. The key result is that the coefficient estimates for Railroad Track are positive and statistically significant for this sample as well. ${ }^{54}$

Finally, our analysis has established a robust partial correlation between railroad penetration, precision weapon development, and military mobilization. We have further discussed why the historical pattern of railroad development makes it unlikely that this correlation is driven by

\footnotetext{
${ }^{52}$ The results are generally weaker for Military Mobilization and the estimate for Railroad Track is not statistically significant for the specification with control variables and a common year trend and only marginally so for the specification with control variables and country-specific year trends.

${ }^{53}$ The sample started with all countries with populations over one million who fought interstate wars during this period. A few countries were eliminated due to missing data. The data sources for this sample are the Correlates of War dataset (2010), The CHAT dataset (Comin and Hobijn 2009), and the Boix and Rosato (2001) democracy measures.

${ }^{54} \mathrm{~A}$ partial exception to this pattern is the estimate for the Military Mobilization specification with countryspecific time trends for which the p-value is 0.166 .
} 


\begin{tabular}{lcccc}
\hline \hline & \multicolumn{4}{c}{ OLS Estimates } \\
\hline & $(1)$ & $(2)$ & $(3)$ & $(4)$ \\
\hline Railroad Track & 10998.810 & 7225.407 & 0.106 & 0.042 \\
& $(3749.792)$ & $(1985.857)$ & $(0.042)$ & $(0.030)$ \\
Population & 0.005 & 0.001 & 0.014 & 0.166 \\
& 0.002 & 0.002 & 0.000 & 0.000 \\
& $(0.001)$ & $(0.002)$ & $(0.000)$ & $(0.000)$ \\
GDP per capita & 0.003 & 0.328 & 0.562 & 0.490 \\
& -68.023 & -58.006 & -0.001 & -0.002 \\
& $(49.785)$ & $(82.586)$ & $(0.001)$ & $(0.001)$ \\
Literacy Index & 0.177 & 0.485 & 0.039 & 0.120 \\
& 0.213 & 1.964 & 0.000 & 0.000 \\
& $(1.452)$ & $(1.328)$ & $(0.000)$ & $(0.000)$ \\
Democracy & 0.884 & 0.145 & 0.854 & 0.197 \\
& 106.548 & 291.022 & 0.012 & 0.010 \\
& $(222.631)$ & $(294.639)$ & $(0.005)$ & $(0.007)$ \\
Country Fixed Effects & 0.634 & 0.327 & 0.024 & 0.161 \\
Common Year Trend & & & & \\
Country-specific Year Trend & Yes & Yes & Yes & Yes \\
Number of Observations & No & No & Yes & No \\
Number of Countries & 601 & 601 & 601 & 601 \\
\hline \hline
\end{tabular}

Table 5: Military Size and Military Mobilization-Expanded Sample, 1816-2000. The table reports the results of pooled-time-series-cross-sectional OLS regressions for the variable Military Size and Military Mobilization on a large cross-section of countries with interstate conflicts for 1816 to 2000. The table reports the coefficient estimate, robust standard error clustered on country (in parentheses), and corresponding p-value. 
states building railroads to pursue their military objectives. That said, it is still possible that there are unobserved factors that led countries during the course of the late 19th and early 20th century to both build railroads and field larger armies. One approach to addressing this concern is to focus on differences in the growth in a single country in army and navy sizes during this period. Our interpretation of any such differences is that they are attributed to the availability of the railroad to move and supply soldiers. This difference-in-differences strategy controls for all unobserved factors which influenced the growth of army and navy sizes similarly over time. It also controls for differences in the specific intensity of the conflicts being compared as long as those differences influenced army and navy participation similarly. Specifically, we have data on army and navy size for the UK during the Napoleonic War and during World War I. ${ }^{55}$ The simple difference-in-differences in army and navy size between these two conflicts is $3,369,733$. To put it slightly differently, while the number of sailors in the navy increased a bit more than $150 \%$, the growth in the size of the army was $1,231 \% .{ }^{56}$ Even the peace-time differences between these two periods was substantial. The difference-in-differences in army and navy size for 1791 — prior to the beginning of the Revolutionary and Napoleonic Wars - and 1913 - prior to World War I - is 101,033. Our interpretation of this differential growth pattern in army and navy sizes is that it is largely due to the ability of railroads to move and supply soldiers, though admittedly any technological or other factors that differentially affected the usefulness of army and naval forces in these conflicts could account for the disparity.

\subsection{Evidence on Conscription Regimes}

The bulk of the evidence that we consider in this paper concerns the scale of military mobilization, either in absolute numbers, or relative to the size of a country's population. However, above we also suggested that there are reasons to believe that states seeking to raise very large armies will be more likely to resort to conscription of one sort or another.

\footnotetext{
${ }^{55}$ We use Navy figures for 1791 and 1813 from House of Commons Parliamentary Papers, 1860 (168). For Navy size in 1913, the source is House of Commons Parliamentary Papers, 1914-16 (96), and we use Navy figures for 1917 from House of Commons Parliamentary Papers, 1928-29 [Cmd. 3253] . The army numbers for 1791, 1813, and 1913 come from Floud, Wachter, and Gregory (1990). The army figure for 1917 is from House of Commons Parliamentary Papers, 1928-29 [Cmd. 3253].

${ }^{56}$ These comparison use 1813 for the Napoleonic War and 1917 for World War I.
} 
If we consider each of the above arguments in light of our claims about technology, then they imply the following causal chain. The state of technology will determine the size of the army that a state will seek to mobilize. This will in turn influence the preferred method of recruitment. To test each of the above two arguments we adopt the following strategy. We repeat the specifications we have employed for Military Size and Military Mobilization while substituting one of two new variables as the dependent variable in the regression. The first variable, Conscription, is a dummy indicator that takes a value of one if a state employs conscription of any form and zero otherwise. We have already presented our operational definition of conscription in the sub-section on recruitment methods. The second variable, Universal Conscription take a value of 1 in cases where universal conscription (as we have previously defined it) is present and zero if there is either non-universal conscription or recruitment without conscription.

Table 6 reports results of OLS estimates with country fixed effects and country-clustered standard errors where we use alternatively Conscription and Universal Conscription as the dependent variable. The results for the Railroad Track variable suggest that the expansion of railroad networks was associated with a shift to universal conscription in particular, but not with the adoption of conscription of all forms. This fits with the descriptive evidence presented in section 4.2. We might also expect that our Cruise Missile variable should be correlated with the type of recruitment regime in place. The availability of cruise missiles might, according to the two alternative theories, be associated with either a shift away from any type of conscription or a shift away form universal conscription in particular. However, in Table 6 the coefficient on the Cruise Missile variable is not statistically significant.

\subsection{Summary}

Overall, the results of our analyses in Tables 3, 4, 5, and 6 provide firm support for our core argument; one revolution in technology, the railroad, made the era of the mass army possible while a second revolution involving remote delivery of explosive force helped bring this era to a

close. The results for the railroad are particularly strong and robust to consideration of a wide variety of factors that might bias our inference. 


\begin{tabular}{lcccc}
\hline \hline & \multicolumn{4}{c}{ Conscription and Universal Conscription } \\
\hline & \multicolumn{4}{c}{ OLS Estimates } \\
\hline & Conscription & Universal & Conscription & Universal \\
\hline Railroad Track & -1.259 & $(2)$ & $(3)$ & $(4)$ \\
& $(4.785)$ & $(1.453)$ & 2.824 & 10.851 \\
Cruise Missile & 0.797 & 0.000 & $0.504)$ & $(1.654)$ \\
& -0.195 & -0.319 & -0.245 & 0.000 \\
Population, Billions & $(0.439)$ & $(0.345)$ & $(0.405)$ & -0.349 \\
& 0.666 & 0.373 & 0.556 & $0.433)$ \\
GDP per capita, Thousands & 1.418 & 1.585 & 2.038 & -3.906 \\
& $(2.197)$ & $(0.823)$ & $(4.446)$ & $(3.880)$ \\
Literacy Quartile & -0.531 & 0.078 & 0.655 & 0.334 \\
& $(0.026)$ & $(0.012)$ & -0.028 & 0.039 \\
Democracy & 0.476 & 0.008 & $0.038)$ & $(0.033)$ \\
& -0.127 & 0.046 & -0.119 & 0.260 \\
& $(0.166)$ & $(0.038)$ & $(0.126)$ & 0.079 \\
& 0.457 & 0.253 & 0.365 & $0.069)$ \\
Country Fixed Effects & 0.293 & 0.128 & 0.045 & 0.208 \\
Common Year Trend & $(0.217)$ & $(0.061)$ & $(0.192)$ & $(0.077)$ \\
Number of Observations & 0.203 & 0.056 & 0.820 & 0.019 \\
\hline \hline
\end{tabular}

Table 6: Conscription in Great Power Wars, 1600-2000. The table reports the results of pooledtime-series-cross-sectional OLS regressions for the variables Conscription and Universal. The table reports the coefficient estimate, robust standard error clustered on country (in parentheses), and corresponding p-value 


\section{Military Mobilization in France}

Our pooled analysis explored the plausibility of our argument emphasizing the importance of technological change in accounting for the scale of warfare. Although there is much to be learned by a closer look at each of our cases, here we focus on France because it is the case that has most informed the thinking of political scientists about the evolution of mass armies. Our discussion of France emphasizes that even in this case, the era of the mass army was largely a late 19th and 20th century phenomena, that coincided with and depended on the technological innovations of the industrial revolution.

Figure 3 presents our variables Military Size and Military Mobilization for France and highlights the peak mobilization years for many of its most important conflicts over the last four centuries. The first thing to notice about the graph is that the 17 th century is a time of dramatic growth in the size of the French army and the extent of mobilization. In our data, the French army reached 362,000 men during the Nine Years' War with a mobilization rate of almost 2 percent. As Lynn (1980, p. 568) puts it, "Henri IV felt it necessary to assemble no more than 55,000 troops in preparation for his still-born campaign of 1610, [while] his grandson Louis XIV required a force of nearly 400,000 during the Nine Years' War (1689-1698).” Lynn, Parker (1976), and others have noted this roughly eight-fold increase in the size of the French army during 17 th century wars. While the determinants of this increase are varied, it is interesting to note that Parker emphasizes, among other factors, the role of transportation. "It was not possible to move large concentrations of troops at speed before the seventeenth century because there were no roads outside Italy which were capable of carrying a large army, its supply train, and its artillery" (1976, pp 209-210). ${ }^{57}$ Although this is not the transportation revolution that we emphasize in this paper, it clearly resonates with our emphasis on how the requirements necessary to move and supply armies placed important limits on the size of army it was desirable to raise.

The size of the French military varied throughout the many conflicts of the 18th century but prior to the French Revolution it did not significantly surpass the scale reached at the end

\footnotetext{
${ }^{57}$ Parker also emphasizes the importance of changes in military technology (the effectiveness of pikemen reducing the relative use of cavalry), innovations in public finance, and improvements in bureaucratic administration.
} 


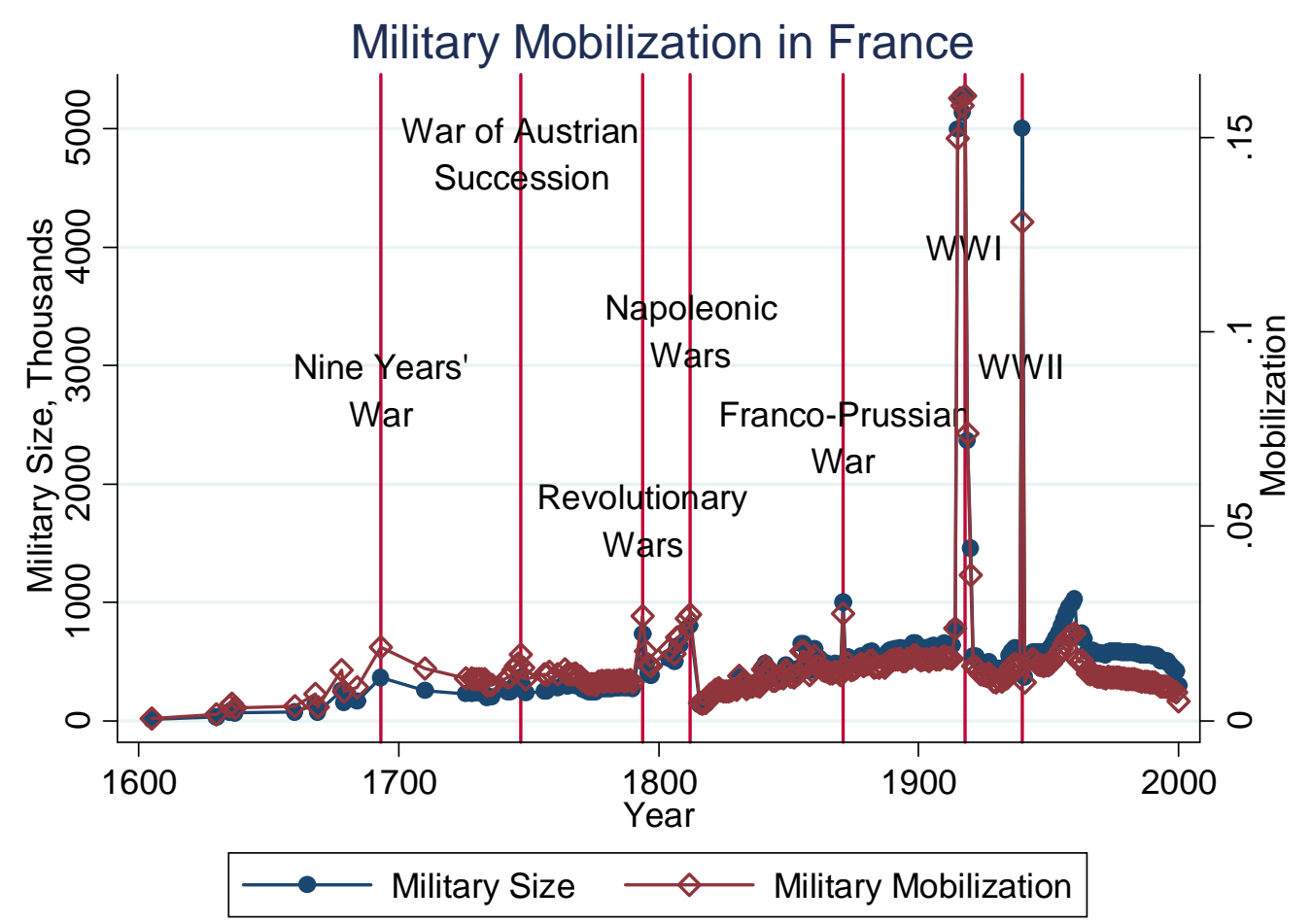

Figure 3: Military Mobilization in France, 1600-2000. Plot of Military Size and Military Mobilization in France. See appendix for sources. Lines indicate peak moblization years for labeled conflicts

of 17th century. Nonetheless, it is important to note that throughout the 18th century France fielded armies that regularly were over two hundred thousand in number and when needed well in excess of three hundred thousand. The high point for 18th century army size in our data is 364,086 during the War of Austrian Succession.

This 18th century experience provides the context for interpreting the changes in military size associated with the French Revolution and Napoleonic Wars. As Figure 3 indicates, army size and mobilization did increase with the French Revolution. Our data suggest that France's revolutionary army included 732,474 soldiers in 1794 which constituted 0.027 of the population. In our data, this increase represents almost precisely a doubling of army size from the previous high point of 1747. Given the substantial population growth during this period, the increase in mobilization was a more modest $60 \%$. It is worth noting that in subsequent years during the revolutionary period, mobilization rates returned to lower levels that were not at all unusual 
in the 18th century (0.017 in 1795, 0.015 in 1796, and 0.014 in 1797). Although our data are not complete for the Napoleonic period, here larger armies and higher mobilization rates were sustained over several years. Army size in our data ranged from 504,220 in 1806 to 800,000 in 1812 with mobilization rates exceeding two percent in four of the six years for which we have estimates, with a peak of 0.027 in 1812. But again, the magnitude of these increases are more modest than is commonly assumed in political science discussions. They were also modest in comparison to the increases that France experienced in the 17th century and would experience in later periods. Peak Napoleonic army size was 2.2 times larger than 1747 and peak Napoleonic mobilization was 1.6 times larger than 1747. Our results regarding the magnitude of the revolutionary and Napoleonic mobilizations may seem surprising in light of received wisdom among political scientists. In fact, our conclusions fall very much in line with recent French historical work regarding the levée en masse in particular. Annie Crepin (2009 pp.106-107) suggests that the levée en masse produced an army that was larger but in the end not that different in scale from the armies raised by Louis XIV toward the end of his reign.

With that said, there was clearly an increase in army size and mobilization associated with the Revolutionary and Napoleonic Wars in France. The most common factor attributed in producing this change is the impact of the revolution in mass politics on mobilization. Mass politics influenced mobilization in at least two ways. First, as discussed above, the revolution is a classic example of a radical change toward more equal citizenship. This, and especially the initial move toward universal conscription, may have made a much broader and more representative set of the population available and willing to serve. This factor seems clearly important but most likely incomplete as an account given that mobilization was if anything higher in the Napoleonic period than the revolutionary period, that some of the advances in citizen rights had been lost, and that conscription had reverted to a more traditional form in which the rich and middle class could avoid service. Second, central to the revolution in mass politics was the development of nationalism, specifically the idea of the "nation in arms." This ideology was clearly related to actual changes in citizen rights but also constituted a change in the connection between individual identity and national service that may have increased France's ability to mobilize and command large armies. One might ask why these historic changes did not result 
in a greater increase in army size and mobilization. Van Creveld's (1977, Chapter 2) account of the challenges of supplying Napoleon's armies strongly suggests that the existing technology of transport and communication limited the size of the armies that France could effectively raise, command, and support. ${ }^{58}$

What happened after the Napoleonic era? While there was debate on the subject, we dispose of clear evidence showing that from a very early date some astute French observers recognized that the military use of the railroad would transform the nature of warfare. For two examples of this belief see Chevalier (1841) and Renouard de Sainte-Croix (1837). We also have clear evidence that after the defeat suffered in the Franco-Prussian war, French observers suggested that Prussia's superior rail system had allowed for the Prussian army to mobilize more quickly and in substantially greater numbers than was the case for the French. For examples of this view see both Jacquemin (1872) and Tomyar (1882).

By 1914, with an extensive rail system France was in a position to mobilize a much larger fraction of its population than ever before. The most striking feature of Figure 3 is the size of the military and levels of mobilization during World War I and more briefly during World War II. Although these mobilizations, which involved over five million soldiers and over 15 percent of the population, were foreshadowed by France's substantial mobilization in the Franco-Prussian War, the scale of the world wars set them apart from France's previous mobilizations including those during the revolutionary and Napoleonic period. In our data, military size in 1918 was 6.6 times larger than in 1812, the peak year of the revolutionary and Napoleonic period. The same multiple for mobilization was 6.0. Even in the French case, it is the late 19th and early 20th century that brings mass warfare involving millions of soldiers to the fore. While the Revolution probably facilitated the ability of the French state to recruit a large army, it was only once the railroads and other innovations in transportation and communication were present that mass warfare became a reality.

Finally, Figure 3 also shows the decrease in army size and mobilization in the late 20th century. This is certainly consistent with our argument that innovations in precision weapons

\footnotetext{
${ }^{58}$ It is worth noting that although we suggest that the development of French nationalism may have had a more modest effect on army size than is often suggested, it may have influenced other important outcomes such as the tactics employed in fighting if, for example, soldiers were less likely to desert because they were motivated by their new political identities. See Costa and Kahn (2008) and Lynn (2000) on this point.
} 
made raising mass armies less desirable but other factors could explain the data just as well. Importantly, France never faced the sort of conflict that would necessitate a large army even if one was both possible and desirable to raise.

\section{Conclusion}

We know relatively little about the factors that have induced and allowed states to field mass armies. There is no shortage of plausible theories, from those focusing on the emergence of nationalism, changes in political regime, or finally technological change. But systematic tests of these arguments have been lacking, and a primary reason for this is that the data constraints for considering changes in military force over the long run are very considerable. In this paper we have attempted a systematic examination of the factors that produced the era of the mass army and which have subsequently led to its demise. This question is important both as a topic in itself, as well as for those interested in understanding the wide variety of important economic and political development outcomes - such as income inequality, progressive taxation, and welfare state development - that have been associated with mass warfare.

Many scholars tend to focus on the importance of political factors when seeking to explain the arrival of the era of the mass army. Nationalism, it is said, provided the motivation necessary for the masses to fight, and the extension of citizenship and democratic rights had a similar effect. But if having soldiers that are motivated is a necessary condition to fielding a mass army, it is certainly not a sufficient one. Fielding a mass army also depends on having the ability to keep it adequately supplied. In addition, governments must actually want to field a mass army as opposed to opting for some other format of military force. We have argued that over the last two centuries these factors depended on the evolution of transportation and communications technology. The railroad and the telegraph made it possible for the first time to field and command armies numbering in the millions. Today, governments could keep a mass army supplied if they wanted to, but further advances in transport and communications technologies have arguably given them less incentive to field one in the first place.

We have tested our argument regarding communications and transport technology using a 
new data set that provides a more extensive view of army sizes, mobilization levels, and recruitment methods among major powers than has previously been possible. Our results regarding the importance of the railroad are quite strong and robust to a number of different types of observable and unobservable confounding factors. Our results regarding cruise missile technology are subject to a greater number of caveats, but they are still consistent with the proposition that the ability to remotely deliver explosive force with precision has been associated with a dramatic reduction in army sizes. Overall, the empirical evidence presented in this paper is strongly consistent with our argument that changes in transport and communications technology were the critical factor in ushering in the era of the mass army and in leading to its subsequent demise. 


\section{References}

[1] Aghion, Philippe, Torsten Persson, and Dorothee Rouzet. 2012. "Education and Military Rivalry." Working Paper.

[2] Atkinson, Anthony and Thomas Piketty. 2007. Top Incomes Over the Twentieth Century. Oxford: Oxford University Press.1

[3] Bai, Jushan, and Pierre Perron. 2003. "Computation and Analysis of Multiple Structural Change Models." Journal of Applied Econometrics 18:1-22.

[4] Bean, Richard. 1973. "War and the Birth of the Nation State." Journal of Economic History. 33:203-221.

[5] Bellows, Henry Adams. 1918. "Moving and Army of Five Million Men." The Bellman, 24:711-722

[6] Bertaud, Jean-Paul. 1988. The Army of the French Revolution. Princeton: Princeton University Press.

[7] Besley, Timothy and Torsten Persson. 2011. Pillars of Prosperity: The Political Economics of Development Clusters. Princeton: Princeton University Press.

[8] Besley, Timothy and Torsten Persson. 2009. "The origins of state capacity: Property rights, taxation, and policy", American Economic Review 99: 1218-1244.

[9] Black, Jeremy. 2007. European Warfare in a Global Context, 1660-1815. New York: Routledge.

[10] Bogart, Dan. 2009. "Nationalizations and the Development of Transport Systems: CrossCountry Evidence from Railroad Networks, 1860-1912." The Journal of Economic History. 69:202-237.

[11] Boix, Carles, and Sebastian Rosato. 2001. "A Complete Data Set of Political Regimes, 1800-1999."

[12] Brewer, John. 1988. The Sinews of Power: War, Money, and the English State 1688-1783. Cambridge: Harvard University Press.

[13] Brodie, Bernard. 1946. "War in the Atomic Age." in Bernard Brodie et al. eds. The Absolute Weapon: Atomic Power and World Order. New York: Harcourt Brace and Company.

[14] Cederman, Lars-Erik, Didier Sornette, and Camber Warren. 2011. "Testing Clausewitz: Nationalism, Mass Mobilization, and the Severity of War." International Organization.

[15] Chandler, David, and Ian, Beckett (eds.). 1996. The Oxford History of the British Army. Oxford: Oxford University Press.

[16] Clausewitz, Carl von. 1832. On War.

[17] Chevalier, Michel. 1841. Cours d'Economie Politique fait au Collège de France. 
[18] Cipolla, Carlo. 1969. Literacy and Development in the West. Penguin Books, Ltd.

[19] Cohen, Eliot. 1996. "A Revolution in Warfare." Foreign Affairs. 75:37-54.

[20] Colley, Linda. 1994. Britons: Forging the Nation, 170\%-183\%. New Haven: Yale University Press.

[21] Comin, Diego, and Bart Hobijn. 2009. "The CHAT Dataset." NBER Working Paper 15319.

[22] Correlates of War Project. 2010. National Material Capabilities Data Version 4.0.

[23] Corvisier, Andre. 1979. Armies and Societies in Europe, 1494-1789. Bloomington: Indiana University Press.

[24] Costa, Dora, and Matthew Kahn. 2008. Heroes and Cowards: The Social Face of War. Princeton: Princeton University Press.

[25] Crépin, Annie. 2009. Histoire de la Conscription. Paris: Gallimard.

[26] Darden, Keith. forthcoming. Resisting Occupation: Mass Schooling and the Creation of Durable National Loyalties. Cambridge: Cambridge University Press.

[27] Dincecco, Mark and Mauricio Prado. 2012. "Warfare, Fiscal Capacity, and Performance." Journal of Economic Growth 17:171-203.

[28] Donaldson, Dave. 2010. "Railroads and the Raj: Estimating the Impact of Transportation Infrastructure." MIT.

[29] Dreze, Jean, and Jackie Toh. 1995. "Literacy in India and China." Economic and Political Weekly 30 (45):2869.

[30] Duffy, Christopher. 1981. Russia's Military Way to the West. London: Routledge and Kegan Paul Ltd.

[31] Eng, Robert and Thomas Smith. 1976. "Peasant Families and Population Control in Eighteenth-Century Japan." Journal of Interdisciplinary History. 6:417-445.

[32] Fearon, James. 1997. "The Offense-Defense Balance and War Since 1648."

[33] Finer, Samuel. 1975. "State- and Nation Building in Europe: The Role of the Military." In The Formation of National States in Western Europe, ed. C. Tilly. Princeton: Princeton University Press.

[34] Fischer, Marie-Joseph. 1925. Comment Dura La Guerre: Souvenirs et Reflexions sur l'Entretien des Armées Francaises au Moyen des Chemins de Fer de 1914 à 1918. Paris:Charles-Lavauzelle.

[35] Forrest, Alan. 1990. The Soldiers of the French Revolution. Durham: Duke University Press.

[36] Fuller, J.F.C.. 1998. Armament and History: The Influence of Armament on History from the Dawn of Classical Warfare to the End of the Second World War, Da Capo Press.

[37] French, David. 1990. The British way in warfare, 1688-2000. London: Unwin Hyman. 
[38] Gagniage, Jean. 1996. "La levée de 1793 en Beauvaisis." in Actes du 2e colloque international organisé par les Archives départementales de l'Oise, Beauvais, 23-24 October 1993. Beauvais: Conseil Général de l'Oise.

[39] García Hernán, Enrique, and Davide, Maffi (eds.). 2006. Guerra y Sociedad en la Monarquía Hispánica: Política, Estrategia y Cultura en la Europa Moderna (1500-1700), Vol. 1. Madrid: Ediciones del Laberinto, Fundación Mapfre, CSIC.

[40] Gennaioli, Nicola, and Hans-Joachim Voth. 2011. "State Capacity and Military Conflict". CEPR Discussion Paper No. DP8699.

[41] Glete, Jan. 2002. War and the State in Early Modern Europe: Spain, the Dutch Republic and Sweden as Fiscal-Military States, 1500-1600. London: Routledge.

[42] Graff, Harvey. 1987. The Legacies of Literacy. Bloomington: Indiana University Press.

[43] Hallion, Richard P. 1995. "Precision Guided Munitions and the New Era of Warfare." Air Power Studies Centre Paper Number 53, Fairbairn, Australia.

[44] Hendricks, Frederick. 1862. "On the Vital Statistics of Sweden from 1749 to 1855", Journal of the Statistical Society of London, 25:111-174.

[45] Hinsley, F.H.. 1962. Power and the Pursuit of Peace: Theory and Practice in the History of Relations Between States. New York: Cambridge University Press.

[46] Hoffman, Philip. 2012. "Why Was it Europeans Who Conquered the World" Journal of Economic History.

[47] Hoffman, Philip. 2011. "Prices, the Military Revolution, and Western Europe's Comparative Advantage in Violence." Economic History Review. 64:39-59.

[48] Huisken, Ronald. 1981. The Origin of the Strategic Cruise Missile. Westport, CT: Praeger Publishers.

[49] Hunter, Janet E. 1984. "Conscription" in Concise Dictionary of Modern Japanese History. Berkeley: University of California Press.

[50] International Institute for Strategic Studies. 1974. Military Balance. London: Routledge Press.

[51] Jacquemin, Francois-Prosper. 1872. Les chemins de fer pendant la guerre de 1870-1871. Paris: Falaize et Girod.

[52] Jervis, Robert. 1978. "Cooperation Under the Security Dilemma." World Politics. 30:167214.

[53] Johansson, Egil. 2009. "The History of Literacy in Sweden." In Eds. Harvey Graff, Alison Mackinnon, Bengt Sandin, and Ian Winchester, Understanding Literacy in its Historical Contexts: Socio-Cultural History and the Legacy of Egil Johansson.

[54] Johnson, Chalmers. 1962. Peasant Nationalism and Communist Power: The Emergence of Revolutionary China, 1937-1945. Stanford University Press. 
[55] Karpat, Kemal. 1978. "Ottoman Population Records and the Census of 1881/82-1893." International Journal of Middle Eastern Studies. 9:237-274.

[56] Krepinivich, Andrew. 2002. "The Military-Technical Revolution: A Preliminary Assessment." Center for Strategic and Budgetary Assessments."

[57] Levi, Margaret. 1997. Consent, Dissent, and Patriotism. New York: Cambridge University Press.

[58] Levy, Jack. 1983. War in the Modern Great Power System, 1495-1975. Lexington: University Press of Kentucky.

[59] Liddell Hart, B. H.. 1954. Strategy. New York: Praeger Paperbacks.

[60] Litton, Leonard. 2000. "The Information-Based RMA and the Principles of War." Air and Space Power Chronicles.

[61] Lynn, John. 2000. "International Rivalry and Warfare." The Eighteenth Century: Europe 1688-1815. Edited by Timoth C.W. Blanning. Oxford: Oxford University Press.

[62] Maddison, Angus. 2003. The World Economy: Historical Statistics. Paris: OECD.

[63] Mahnken, Thomas. 2011. "Weapons: The Growth and Spread of the Precision Strike Regime." Daedalus. Summer 2011. pp.45-57.

[64] McNeill, William H. 1984. The Pursuit of Power. Chicago: University of Chicago Press.

[65] Mironov, Boris. 1991. "The Development of Literacy in Russia and the USSR from the Tenth to the Twentieth Centuries." History of Education Quarterly 31(2).

[66] Mitchell, Brian R. 1988. British Historical Statistics. Cambridge: Cambridge University Press.

[67] Mitchell, Brian R. 2007a. International Historical Statistics: Europe, 1750-2005 - 6th ed. Palgrave Macmillan.

[68] Mitchell, Brian R. 2007b. International Historical Statistics: The Americas, 1750-2005 6th ed. Palgrave Macmillan.

[69] Mitchell, Brian R. 2007c. International Historical Statistics: Africa, Asia \& Oceania, 1750-2005 - 5th ed. Palgrave Macmillan.

[70] Mokyr, Joel. 1990. The Lever of Riches: Technology Creativity and Economic Progress. Oxford: Oxford University Press.

[71] Murray, Williamson and MacGregor Knox. 2001. "Thinking About Revolutions in Warfare." in Macgregor Knox and Williamson Murray (eds.) The Dynamics of Military Revolution, 1300-2050. New York: Cambridge University Press.

[72] National Center for Education Statistics. 120 Years of American Education: A Statistical Portrait. Washington DC: U.S. Department of Education. 
[73] National Defense Industrial Association. 1999. "Feasibility of Third World Advanced Ballistic and Cruise Missile Threat, Volume 2: Emerging Cruise Missile Threat." National Defense Industrial Association, Systems Assessment Group Report.

[74] North, Douglass C., and Barry Weingast. 1989. "Constitution and Commitment: The Evolution of Institutional Governing Public Choice in Seventeenth-Century England." The Journal of Economic History 49(4):803-832.

[75] O'Brien, Patrick. 2011. "The Nature and Historical Evolution of an Exceptional Fiscal State and its Possible Significance for the Precocious Commercialization and Industrialization of the British Economy from Cromwell to Nelson." Economic History Review. 64:408-446.

[76] Oomens, Cees and Gert den Bakker. 1997. "Dutch Historical Statistics: 19th Century Population Censuses" Netherlands Official Statistics. 12:5-17.

[77] Orleans, Leo. 1957. "The 1953 Chineses Census in Perspective." The Journal of Asian Studies. 16:565-573.

[78] Pamuk, Sevket. 2009. "Estimating GDP per capita for the Ottoman Empire in a European Comparative Framework, 1500-1820." Paper presented at the XVth World Economic History Congress.

[79] Pamuk, Sevket, and Jan-Luiten van Zanden. 2010. "Standards of living." in The Cambridge Economic History of Modern Europe, Volume 1: 1700-1870. Eds. Broadberry, Stephen, and Kevin H. O'Rourke. New York: Cambridge University Press, pp. 217-234.

[80] Parker, Geoffrey. 1972. The Army of Flanders and the Spanish Road 1567-1659. Cambridge: Cambridge University Press.

[81] Parker, Geoffrey. 1976. "The 'Military Revolution' 1560-1660 - a Myth?" The Journal of Modern History Vol. 48 No. 2:195-214.

[82] Pigeard, Alain. 2003. La conscription au temps de Napoléon. Paris: Bernard Giovanangeli, editor.

[83] Piketty, Thomas. 2001. Les hauts revenus en France au XXème siècle. Paris: Grasset.

[84] Posen, Barry. 1993. "Nationalism, the Mass Army, and Military Power." International Security.

[85] Pratt, Edwin. 1915. The Rise of Rail Power in War and Conquest 1833-1914.

[86] Przeworski, Adam. 2009. "Conquered or Granted? A History of Suffrage Extensions." British Journal of Political Science. 39:291-321

[87] Renouard de Sainte-Croix, Félix. 1837. Des chemins de fer considérés comme moyen de défense du territoire francais. Paris: Imprimerie de Guiraudet et Ch. Jouast.

[88] Roberts, Michael. 1956. "The Military Revolution, 1560-1660". Belfast.

[89] Ropp, Theodore. 1959. War in the Modern World. Baltimore: Johns Hopkins University Press. 
[90] Ross, Heidi. 2005. "China country study." Paper commissioned for EFA Global Monitoring Report 2006, Literacy for Life.

[91] Ross, Thomas. 1994. "Raising an Army: A Positive Theory of Military Recruitment." Journal of Law and Economics.

[92] Rothenberg, Gunther. 1973. "The Habsburg Army in the Napoleonic Wars." Military Affairs February:1-5.

[93] Sagan, Scott. 1986. "1914 Revisited: Allies, Offense, and Instability." International Security. 11:151-175.

[94] Scheve, Kenneth, and David Stasavage. 2010. "The Conscription of Wealth: Mass Warfare and the Demand for Progressive Taxation." International Organization Vol. 64 (Fall):52961 .

[95] Scheve, Kenneth, and David Stasavage. 2012. "Democracy, War, and Wealth: Lessons from Two Centuries of Inheritance Taxation." American Political Science Review.

[96] Schnapper, Bernard. 1968. Le remplacement militaire en France: Quelques aspects politiques, économiques et sociaux du recrutement au XIX siècle. Paris: S.E.V.P.E.N.

[97] Shimshoni, Jonathan. 1990. "Military Advantage, and World War I: A Case for Military Entrepreneurship." International Security. 15:187-215.

[98] Sidgwick, Henry. 1883. The Principles of Political Economy. London: Macmillan.

[99] Sidgwick, Henry. 1903. The Development of European Polity. London: Macmillan.

[100] Singh, Sonali, and Christopher Way. "The Correlates of Nuclear Proliferation: A Quantitative Test." International Organization 48(6): 859-885.

[101] Snyder, Jack. 2000. From Voting to Violence: Democratization and Nationalist Conflict. New York: W.W. Norton.

[102] Snyder, Jack. 1984. "Civil-Military Relations and the Cult of the Offensive, 1914 and 1984." International Security. 9:108-146.

[103] Stasavage, David. 2010. "When Distance Mattered: Geographic Scale and the Development of European Representative Assemblies." American Political Science Review. 104:625-643.

[104] Stasavage, David. 2011. States of Credit: Size, Power, and the Development of European Polities. Princeton: Princeton University Press.

[105] Stone, Lawrence. 1969. "Literacy and Education in England 1640-1900." Past \& Present 42 .

[106] Taylor, AJ. 1951. "The Taking of the Census: 1801-1951." British Medical Journal.

[107] Thompson, William R., and Karen Rasler. 1999. "War, The Military Revolution(s) Controversy, and Army Expansion: A Test of Two Explanations of Historical Influences on European State Making." Comparative Political Studies Vol. 32 No. 1 (February):3-31. 
[108] Ticchi, Davide and Andrea Vinding. 2008. "War and endogenous democracy". IZA Discussion Paper No. 3397

[109] Tilly, Charles, 1990. Coercion, Capital, and European States. Cambridge: Blackwell.

[110] Tilly, Charles. 1975. "Reflections on the History of European State Making." In The Formation of National States in Western Europe, ed. C. Tilly. Princeton: Princeton University Press.

[111] Titmuss, Richard. 1950. Problems of Social Policy.

[112] Titmuss, Richard. 1958. "War and Social Policy" in Essays on the Welfare State. London: George Allen and Unwin.

[113] Tomyar, Charles. 1882. L'état et les chemins de fer. Paris: Librairie Militaire de J. Dumaine.

[114] Tortella, Gabriel. 1994. "Patterns of Economic Retardation and Recovery in SouthWestern Europe in the Nineteenth and Twentieth Centuries." The Economic History Review $47(1)$.

[115] Tracy, James. 1985. A Financial Revolution in the Habsburg Netherlands, 1515-1565. Berkeley: University of California Press.

[116] Troyansky, David G., Alfred Cismaru, and Norwood Andrews, Jr., (eds.). 1991. The French Revolution in Culture and Society. Westport, CT: Greenwood Press.

[117] van Creveld, Martin. 1977. Supplying War: Logistics from Wallenstein to Patton. New York: Cambridge University Press.

[118] van Creveld, Martin. 1989. Technology and War from 2000 B.C. to the Present. New York: The Free Press.

[119] van Evera, Stephen. 1984. "The Cult of the Offensive and the Origins of the First World War." International Security. 9:58-107.

[120] van Evera, Stephen. 1998. "Offense, Defense, and the Causes of War." International Security. 22:5-43.

[121] Walt, Stephen. 1992. "Revolution and War." World Politics. 44:321-368.

[122] Walter, Dierk. 2009. "Meeting the French Challenge: Conscription in Prussia, 1807-1815." In Stoker et al (eds.) Conscription in the Napoleonic Era.

[123] Werrell, Kenneth. 1985. The Evolution of the Cruise Missile. Maxwell Air Force Base, Alabama, Air University Press.

[124] Westwood, John. 1980. Railways at War. San Diego: Howell North Books.

[125] White, Lynn. 1962. Medieval Technology and Social Change. Oxford University Press.

[126] Wolmar, Christian. 2010. Engines of War: How Wars Were Won and Lost on the Railways. New York: Public Affairs. 


\section{A Appendix: Data on Military Mobilization}

We have constructed a new data set on military mobilization for great powers from 1600 to 2000 . We adopt Levy's (1983) definition of a great power as "a state that plays a major role in international politics with respect to security-related issues" (p. 16) and adopt his operationalization of the definition. This creates a sample of thirteen states which were great powers during some portion of the 1600 to 2000 period.

The key variable in the data set is Military Size which is defined as troops under the command of the national government and intended for use against foreign adversaries. This definition does not include reserve troops, colonial troops, civil defense units, and domestic police forces. A common problem with statistics on the size of the military is that states have an incentive to inflate them. We made efforts to use numbers that reflected "actual" or "effective" forces rather than "paper" forces wherever possible. This included reading historiographies that discussed potential differences between reported army sizes and actual troops raised. However, for some cases, the only information we have is on the reported size of the army by the government and these numbers may exaggerate the size of the military, particularly in earlier periods. The data discussion for each case provides notes on this issue.

\section{Austria-Hungary 1600-1918}

Our data for Austria-Hungary's military for the 17th century is somewhat limited and of uneven quality. Our initial data are for 1625-1630 and are from Wilson (2009, p. 395, Table 3). For each year, we report his estimates of the probable effective size of the imperial army in the Thirty Years War. We do not include any other estimates for the size Austria-Hungary's forces during the Thirty Years War. Wilson (2009), however, suggests that these forces were not larger than during this early period. For the years 1649, 1650, 1655, 1656, 1661, 1664, 1668, 1673, 1675, 1677, 1679, 1681, 1683, 1684, 1685, and 1687, we have estimates from Hochedlinger (2003, p. 104, Table 3). These numbers are primarily estimates of effective strength except for 1664, 1679, 1684, and 1685. For the years 1695 to 1794, Dickson (1987b, p343-352) provides data on official infantry and cavalry sizes for the Empire. These official numbers, therefore, reflect an upper bound of the size of Austrian-Hungarian forces. We identified estimates of Austrian-Hungarian forces for 1809 and 1813 in Rothenberg (1973). The latter number indicates the high point of Austrian-Hungarian mobilization during the Napoleonic Wars and should also be treated as an official, possibly inflated estimate. Finally, for 1816 to 1918, we used Correlates of War, National Material Capabilities, Version 4.0 (2010) numbers for the size of Austria-Hungary's military forces.

Population data for Austria-Hungary are also from several sources. For 1600 and 1650, we used data reported in Wilson (2009, p. 788, Table 8). For 1740, 1754, 1762, 1768, and 1787, the data are from Dickson (1987a, p. 36, Table 2.5) and refer to the central lands of the Habsburg monarchy. Finally, for 1816 through 1918, the data are from the Correlates of War Project (2010). Missing years for population were interpolated.

\section{China 1949-2000}

We used military personnel and population data from Correlates of War (2010) for China. These data should be interpreted cautiously as they may inflate the actual size of Chinese forces. We note further that for the period just prior to China's great power status, Gittings (1967 pp. 
303-305) provides an informative account of the People's Liberation Army from the beginning of the Japanese war in 1937 through 1958. Since these figures are only for the PLA and not the KMT army during the anti-Japanese war and subsequent civil war, total Chinese mobilization during this period will be understated. Gittings (p. 1) also provides partial details on the size of the KMT army. He suggests 1.5 million troops in 1945 and 1.5 million again in 1947. Gittings also suggests that official figures for the KMT army were substantially higher (upwards of 5 million) raising again the issue of inflated official numbers.

\section{France 1600-2000}

Data on the French army during the 17th century are from three sources: David Parrott (2001), John Lynn (1997) and John Lynn (2006). Our first figure is from Parrott (2001, p. 183). It represents the peacetime establishment of the army in the first decade of the 17th century. We use this number for the year 1605. The figure for 1630 is also from Parrott (2001, p. 187). Parrott (2001, p. 194) mentions that "some 65,000 infantry and 9,000 - 9,500 cavalry were briefly operational" at the beginning of the 1635 campaign. We use the number of 74,250 for this year. According to Parrott (2001, p. 199), for a short period in 1636, France probably reached the highest number of men under arms ("70,000 - 80,000 infantry and 10,000 - 15,000 cavalry") during the time of Richelieu and Mazarin. We use for this year the number of 87,500 given by the sum of mid-point estimates for the size of both the infantry and the cavalry. On the basis of Parrott (2001, p. 202) who writes that probably "some 60,000 - 70,000 infantry and cavalry were either in existence or levied during the first months of 1637 ", we use the figure of 65,000 for this year. The figure for 1660 is from Lynn (1997, p. 45 and Table 2.1, p.55; 2006, p. 53) and gives the official peacetime strength of the army. Additional figures provide estimates of the size of the army during the wars that France fought in the second half of the 17th century. According to Lynn (1997, p. 46 and Table 2.1, p. 55; 2006, p. 54), the strength of the army in 1668 (during the War of Devolution) was on paper 134,000 men. Data for the years 1678 (Lynn, 1997, p. 46, p. 51 and Table 2.1, p. 55; Lynn, 2006, p. 54) and 1693 (Lynn, 2006, p.57) are estimates of the effective size of the army during the Dutch War and the Nine Years' War, respectively. Further data refer to the official strength of the army in years of peace in the second half of the 17th century. The first one (year 1669) is provided by Lynn (1997, p. 46; 2006, p. 53). The second one is for the year 1679 (Lynn, 1997, p. 46; Lynn, 2006, p.53); the third one refers to the year 1684 (Lynn, 1997, p. 47; Lynn, 2006, p.53).

Our first data for the 18th century (year 1710) is from Lynn (1997, p. 48 and p.55; 2006, p. 54 and p. 58) and it gives an estimate of the actual strength of the army during the War of Spanish Succession. Data for the period 1720-1790 are from two sources: Sturgill (1991) and Gebelin (1881). The former provides figures about the strength of the army. Before 1763, this source includes the militia only if it was on active service (see Sturgill, 1991, p. 129). Sturgill's figures, therefore, do not comprise the militia for the years of peace and of war demobilization before 1763. Prior to that year, militia figures are not included in the army's strength also for some of the years of war preparation $(1720,1726-27,1756)$ and are missing for some of the years of war (1757-63). When Sturgill's figures on the army's strength do not incorporate the militia, we add to them the number of effectives of the provincial militias (soldiers and officers) provided by Gebelin (1881, p. 285). Finally, for the years from 1720 to 1763 in which figures on the militia are not available either from Sturgill or from Gebelin, we assign a missing value to our series. By adopting these coding criteria, we are able to compute figures on the strength of the army including the militia for the following years: 1726, 1728-1736, 1742-1749, 1756-1758, 
and 1761. Starting from 1764, figures on the strength of the army provided by Sturgill include militia and miscellaneous units, so we use these data for the years from 1764 to 1790 . These figures should be considered as an upper bound estimate of the French army, since, as Sturgill (1991, p. 131) points out, militia troops were not likely to be ready immediately in the case of a mobilization for war. Data for the years 1794-97 are troop estimates reported to the Assembly. They are provided by Bertaud (1988, p. 272).

As it concerns the Napoleonic period, the figures for the years 1804, 1806-8, and 1811-12 are taken from Delmas (1992, p. 317). They represent the paper strength of the Imperial Army. Finally, the figures on the size of the military forces for the period 1816-2000 are from Correlates of War, National Material Capabilities, Version 4.0 (2010).

Data for our time series of the French population are taken from several sources. Figures for the years 1600, 1650 and 1700 are from De Vries (2007, p. 36, Table 3.6). We use the estimates of the French population provided by Mathias and O' Brien (1976, p. 604, Table 1) for the years $1715,1725,1730,1735,1740,1745,1750,1755,1765,1770,1775,1780,1785$, and 1790 . We take the data for the years 1801 - 1945 from Institut National de la Statistique et des Études Économiques (1966, p. 66-73, Tables 1 A - 1 D); for the years 1946 - 1984 from Institut National de la Statistique et des Études Économiques (1990, p. 26, Table 1); for the years 1985-1994 from Institut National de la Statistique et des Études Économiques (1997, p. 49, Table B.01-1); for the years 1995-99 from Institut National de la Statistique et des Études Économiques (2002, p. 49, Table B.01-1); for the year 2000 from Institut National de la Statistique et des Études Économiques (2007, p. 41, Table B.01-1). Missing data in our time series of the population have been interpolated.

\section{Italy 1861-1943}

We used military personnel from the Correlates of War (2010) for Italy. The population data come from Istituto Centrale di Statistica (1976), Sommario di Statistiche Storiche dell'Italia 1861-1975, Table 10 Popolazione residente calcolata a fine anno dal 1861 al 1975, p.16, Roma.

\section{Japan 1905-1945}

We used military personnel from Correlates of War (2010) for Japan. The population data come from Ministry of Internal Affairs and Communications, Statistics Bureau, Historical Statistics of Japan, Chapter 2 Population and Household, Population by Sex, Population Increase and Decrease, Population Density (1872-2009) (Accessed at: http://www.stat.go.jp/english/ data/chouki/02.htm).

\section{Netherlands 1609-1713}

We used two principal sources for estimating Dutch army strength. Most historians use the Staatsche Leger, an early twentieth century source that although it sounds archival was not. These numbers should be treated as nominal or paper strength. Van Nimwegen (2006) presents a more contemporary set of estimates of effective strength. We use van Nimwegen wherever possible, but use the Staatsche Leger when we have no other estimates. To summarize, we use van Nimwegen for 1609 (this actually van Nimwegen's number for 1608 but is the closest number we have for the start of the period), 1629, 1640, and 1672 and the Staatsche Leger for 1618, $1625,1635,1645,1657,1667,1675,1683,1692,1699$, and 1708. The population data is from Maddison (2003) and is linearly interpolated. 


\section{Ottoman Empire 1600-1699}

The Ottoman army during the 17th century was comprised primarily of two groups. The first group is the sultan's permanent, standing army made of infantry (Janissaries), cavalry, and the artillery corps. We have estimates for this total for eleven years during the 17th century. The second group is the seasonally-mobilized, provincial cavalry. For 1609, our estimate of the standing army is from Murphey (1999). For 1660, we used Agoston (1999) and Murphey (1999) for the infantry estimate and Agoston (2005) for the artillery corps estimate. We used Murphey's (1999) estimate for the standing cavalry in 1670 to estimate the size of the cavalry in 1660. For 1670, we used Murphey (1999). For 1687, 1690-94, 1996, and 1698, we used Tabakoglu (1985) for our estimate of the total standing army. We relied on the discussion in Murphey (1999) and Aksan (2007) to arrive at a single estimate of 70,000 for the effective size of the provincial cavalry. This number is added to the total standing army for the eleven years that we have data for the 17th century to compute our total estimate for each year.

The population data is from McEvedy and Jones (1978) for 1600 and 1700 and is linearly interpolated. See Braudel (1972), Barkan (2000), and Quataert (2000) for additional estimates and discussion.

\section{Prussia/Germany/West Germany 1740-2000}

For Prussia, data on military strength is available from a number of sources including Craig (1955), Wilson (1998), Jany (1914), Correlates of War (2010), and the European State Finance Database. From 1740 to 1870, we rely primarily on Jany because his numbers are the most complete time series and are very close to the numbers in the other sources. In all cases, every effort was made to report either actual troop numbers or estimates adjusted to reflect actual troop strength. From 1871 to 2000, we use Correlates of War (2010) numbers. The data for 1955 to 1989 are for West Germany only.

Population data for Prussia for 1740 to 1865 are from Dincecco (2009) and for 1866 to 1870 are from Mauersberg (1988). We use Correlates of War population data for the remaining years of the series and again the data for 1955 to 1989 are for West Germany only.

\section{Russia/Soviet Union 1721-2000}

Our data for Russia's military in the eighteenth and early nineteenth century are collected from a number of sources. The value for 1721 comes from a 1720 budget approved by Peter the Great (Keep 1985, p. 137); as such, the number most likely reflects an upper bound on the actual army size. Values for 1725, 1731, 1734, 1740, 1756, 1763, 1765, 1795, 1796 all come from Pintner (1984; estimates for 1740 and 1756 come from p. 233, and the rest are from p. 253, Table 5). For the table, Pintner cites two sources: von Stein (1859, pp. 92, 100, 151, 359) and Beskrovny (1959, pp. 58, 330). The data points for 1801, 1811, and 1815 are estimates of the Russian State Military Archives (RGVIA) as reported by Beskrovny (1973, pp. 12, 15). For all reported estimates, we attempted to validate all numbers with estimates from other sources for the same time period. From 1816 onwards, we take for the size of Russia's military forces from Correlates of War (2010).

We take estimates of Russia's population before 1816 from Kabuzan (1963, p. 164, Table 18). These data comes from a series of revisions to an unpublished 1702 government census: 1719, 1744, 1762, 1728, 1795, 1811, 1815. From 1816-2007, we use population estimates from Correlates of War (2010). Missing years for population were interpolated. Note: the first data 
point for population in the series (1721) is the number reported in the 1719 revision to the census.

\section{Spain 1600-1808}

For Spain, we have limited information about the size of the military. For 1600, we use Parker's (1976, p. 206, Table 1) estimate for the 1590s. Similarly, we use Parker (1976) for estimates for 1635, 1655, 1675, and 1705. Unfortunately, we have no further estimates on the overall size of the Spanish military for the remainder of the 18th century and into the 19th century when they were a great power. Parker (1972) provides additional detailed information on the Army of Flanders but again this data is for the 17th century. Population data is from Maddison (2003) and is linearly interpolated.

\section{Sweden 1617-1721}

For Swedish military forces, we have several high quality sources including Roberts (1968), Roberts (1979), Aberg (1973), and Nordmann (1972). These sources, however, provide numbers for only six years during the period that Sweden was a major power. We use Nordmann (1972, p. 135 ) for 1630. For 1632, we use Roberts (1979, p. 44). Nordman cites a lower figure for this year but this is derived from earlier work by Roberts. We again use Nordmann for 1637 (p. 137), 1697 (p. 141), 1700 (p. 143), and 1707 (p. 144). Finally, Roberts (1979, p. 45) provides a number for 1708. Population data is from Maddison (2003) and is linearly interpolated.

\section{United Kingdom 1600-2000}

The first two data on the size of the army in the 17th century refer to the years 1652 and 1660 . They are provided by Firth (1902, p. 35). We use figures on the strength of the army from Childs (1996, p. 47) for the years 1670 and 1678. For the year 1685 (December), we report the data on the number of soldiers in England under James II provided by Childs (1980, p. 2). Two additional figures refer to the official strength of the army at the end of October 1688 (Childs, 1980, p. 3) and in April 1689 (Childs, 1987, p. 102). It is worth noting that the last number does not include the Dutch troops stationing in England in that year (on this point, see Childs, 1987, p. 102 and French, 1990, p. 8). The main source for our data on the British military forces for the years from 1691 to 1815 is Floud, Wachter, and Gregory (1990). For the period 1691-1714 we use their data on the establishment of the army (Floud, Wachter, and Gregory, 1990, p. 44, Table 2.1). The official strength of the British military forces for the years 1715, 1718-19, 1723, and 1728-55 is given by the sum of the establishment of the army (Floud, Wachter, and Gregory, 1990, pp. 44-45, Table 2.1) and of the navy (Floud, Wachter, and Gregory, 1990, p. 68, Table 2.6). For the period 1756-1773 we add up the figures for the establishment of the army (Floud, Wachter, and Gregory, 1990, p. 45, Table 2.1), of the navy and of the marines which are reported in Floud, Wachter, and Gregory, 1990, pp. 68-69, Table 2.6. For the period going from the year 1774 to the year 1815, we are able to provide estimates of the actual strength of the British military forces. In specific, for the years 1774-83 and 1785-1815 we use data on the effective size of the army provided by Floud, Wachter, and Gregory, 1990, pp. 45-46, Table 2.1. We add to these numbers the figures about the "Seamen (including Officers), Boys, and Marines (...) actually Borne" in the naval service for the years 1774-83 and 1785-1815. The source for these last data is the House of Commons Parliamentary Paper, 1860 (168). For the years 1816-2000 we use the data on the military forces provided by Correlates of War (2010). 
The time series of the total population is constructed in the following manner. For the years from 1600 to 1706 we take the population of England and Wales. We add the population of Scotland to that of England and Wales for the period 1707 - 1800. For the years going from 1801 to 1921 we sum the population of Ireland to that of England, Wales and Scotland. Finally, for the years from 1922 to 2000 the total population corresponds to the sum of the population of England \& Wales, Scotland and Northern Ireland.

The source for the total population of England and Wales in the years 1650 and 1700 is De Vries (2007, p. 36, Table 3.6). Missing data are interpolated. We take the estimates of the Welsh population in 1701, 1751, 1781, and 1801 from Deane and Cole, 1967, p. 103, Table 24. Missing values are interpolated. We use these data as an estimate of the population of Wales for the years 1701 to 1800. The source for the population of England (which does not include Monmouthshire) for the years $1701-1800$ is Mitchell (1988, pp. 7-8). Mitchell (1988, pp. 11-14) provides data on the overall population of England \& Wales for the years 1801 to 1980. We turn to Deane and Cole (1967, p. 6, Table 2) for estimates of the population of Scotland in 1701, 1751, 1791, and 1801. We interpolate missing data and use this series for the years 1707 - 1800. We take data on the Scottish population for 1801 - 1980 from Mitchell (1988, pp. 11-14). Figures on the population of Ireland for 1801-1921 are taken from Mitchell (1988, pp. 11-13). The population of Northern Ireland for the years 1922 - 1980 are provided by Mitchell (1988, pp. 13-14). Finally, the data on the population of the United Kingdom for the years 1981 - 2000 are taken from the Office of National Statistics, Population estimates for UK, England and Wales, Scotland and Northern Ireland - current datasets. Data are available at: http://www.statistics.gov .uk/statbase/Product. asp?vlnk=15106.

\section{United States 1898-2000}

The military personnel data for 1898 to 1995 are active duty personnel from all branches excluding the Coast Guard. The source for these data is the Historical Statistics of the United States, vol. 5, Table Ed26-47, Military personnel on active duty, by branch of service and sex: 1789-1995, p. 5-353-359. The data for 1996 to 2000 are from Correlates of War (2010). The population data for the United States for 1898 to 1929 are from the Historical Statistics of the United States, vol. 1, Table Aa9-14, National population and the demographic components of

change: 1790-2000, p. 1-30-33. From 1930 to 1949, we used Historical Statistics of the United States, vol. 1, Table Aa6-8, Population 1790-2000, p. 1-28-29. And from 1950 to 2000, the population data are from U.S. Census Bureau, National Estimates and Projections, Table 2, Population, accessed from http://www.census.gov/compendia/statab/cats/population.html. 


\section{References}

[1] Aberg, Alf. 1973 "The Swedish Army, from Lutzen to Narva." in Michael Roberts (ed.) Sweden's Age of Greatness: 1632-1718. New York: St. Martin's Press.

[2] Agoston, Gabor. 1999. "Ottoman Warfare in Europe 1453-1826." In European Warfare 14531815, Jeremy Black (Ed.), New York: St. Martin's Press.

[3] Agoston, Gabor. 2005. Guns for the Sultan: Military Power and the Weapons Industry in the Ottoman Empire. New York: Cambridge University Press.

[4] Aksan, Virginia H. 1999. "Ottoman War and Warfare 1453-1812." In War in the Early Modern World, Jeremy Black (Ed.), Boulder, Colorado: Westview Press.

[5] Aksan, Virginai H. 2007. Ottoman Wars 1700-1870: An Empire Besieged. Harlow, England: Pearson Education.

[6] Barkan, O.L. 2000 [1953]. “Tarihi Demografi' Arastirmalari ve Osmanli Tarihi." In Osmanli Devleti'nin Sosyal ve Ekonomik Tarihi: Osmanli Devlet Arsivleri Uzerinde Tetkikler Makaleler, Cilt 2. H. Ozdeger (Ed.) Istanbul: Istanbul Universitesi Rektorluk Yayini.

[7] Beskrovny, Lubomir. 1973. Russkaia Armiia I Flot v XIX Veke (ocherki). Moscow: Nauka Publishing.

[8] Beskrovny, Lubomir. 1958. Russkaia Armiia I Flot v XVIII Veke (ocherki). Moscow.

[9] Braudel, F. 1972. The Mediterranean and the Mediterranean World in the Age of Philip II, trans. by S. Reynolds, Vol. I, New York: Harper \& Row Publishers.

[10] Cheng, Sijin. 2007. "The Challenge of Conscription in an Era of Social Change." in CivilMilitary Relations in Today's China: Swimming in a New Sea, eds. David M. Finkelstein and Kristen Gunness. New York: M.E. Sharpe.

[11] Childs, John. 1980. The Army, James II, and the Glorious Revolution. Manchester: Manchester University Press.

[12] Childs, John. 1987. The British army of William III, 1689-1702. Manchester: Manchester University Press.

[13] Childs, John. 1996. "The Restoration Army 1660-1702" in Chandler and Beckett (eds.). 1996. Oxford: Oxford University Press.

[14] Clode, Charles Mathew. 1869. The Military Forces of the Crown: Their Administration and Government, Vol. 2. London: John Murray.

[15] Coxe, William. 1820. History of the House of Austria, from the Foundation of the Monarchy by Rudolph of Hapsburgh, to the Death of Leopold the Second: 1218 to 1792. London: Longman, Hurst, Rees, Orme, and Brown, Paternoster-Row.

[16] Craig, Gordon. 1955. The Politics of the Prussian Army 1640-1945. Oxford: Clarendon Press. 
[17] Deane, Phyllis, and W. A., Cole. 1967. British economic growth, 1688-1959: trends and structure. 2nd edition. London: Cambridge at the University Press.

[18] Delmas, Jean. 1992. Histoire Militaire de la France. Vol.2 1715-1871. Paris: Presses Universitaires de France.

[19] De Vries, Jan. 2007. European Urbanization, 1500 - 1800. London: Routledge Library Editions: The City.

[20] Dincecco, Mark. 2009. "Fiscal Centralization, Limited Government, and Public Revenues in Europe, 1650-1913." The Journal of Economic History Vol. 69 No. 1:48-103..

[21] Dickson, P.G.M. 1987a. Finance and Government under Maria Theresia 1740-1780, Vol. 1. Oxford: Clarendon Press.

[22] Dickson, P.G.M. 1987b. Finance and Government under Maria Theresia 1740-1780, Vol. 2. Oxford: Clarendon Press.

[23] Duffy, Christopher. 1977. The Army of Maria Theresa: The Armed Forces of Imperial Austria, 1740-1780. London: David \& Charles.

[24] Firth, Charles H. 1902. Cromwell's Army. London: Methuen \& Co.

[25] Floud, Roderick, Kenneth, Wachter, and Annabel, Gregory. 1990. Height, health and history: nutritional status in the United Kingdom, 1750 - 1980. Cambridge: Cambridge University Press.

[26] Gates, David. 1996. "The Transformation of the Army 1783-1815." in Oxford History of the British Army.

[27] Gebelin, Jacques. 1881. Histoire des milices provinciales (1688-1791). Paris: Hachette.

[28] Gittings, John. 1967. The Role of the Chinese Army. New York: Oxford University Press.

[29] Hochedlinger, M. 2003. Austria's Wars of Emergence. London: Pearson Education Limited.

[30] House of Commons Parliamentary Papers. 1860 (168). Navy. Available at: http://parlipapers.chadwyck.com/home.do.

[31] House of Commons Parliamentary Papers. 1914-16 (96). Navy. Appropriation account, 19131914. Available at: http://parlipapers.chadwyck.com/home.do.

[32] House of Commons Parliamentary Papers. 1928-29 [Cmd. 3253]. Board of Trade. (In conjunction with the Ministry of Labour and the registrars-general.) Statistical abstract for the United Kingdom for each of the fifteen years from 1913 to 1927. Seventy-second number. Available at: http://parlipapers.chadwyck.com/home.do.

[33] Institut National de la Statistique et des Études Économiques. 1966. Annuaire Statistique de la France. 1966. Résumé Rétrospectif. Paris.

[34] Institut National de la Statistique et des Études Économiques. 1990. Annuaire Rétrospectif de la France 1948 1988. Paris. 
[35] Institut National de la Statistique et des Études Économiques. 1997. Annuaire Statistique de la France. Édition 199\%. Paris.

[36] Institut National de la Statistique et des Études Économiques. 2007. Annuaire Statistique de la France. Édition 200\%. Paris.

[37] Istituto Centrale di Statistica. 1976. Sommario di Statistiche Storiche dell'Italia 1861-1975.

[38] Jany, Curt. 1928. Geschichte de Preussischen Armee vom 15. Jahrhundert bis 1914.

[39] Kabuzan, B. M. 1963. Narodnaceleniye Rossii v XVIII - pervoi polovinye XIX vekov. Moscow: USSR Academy of Sciences.

[40] Keep, John L. H. 1985. Soldiers of the Tsar: Army and Society in Russia 1462-1874. Oxford: Clarendon Press.

[41] Lynn, John A. 1980. "The Growth of the French Army during the Seventeenth Century." Armed Forces \& Society Vol 6:568-585.

[42] Lynn, John A. 1997. Giant of the Grand siècle: the French Army, 1610-1715. Cambridge: Cambridge University Press.

[43] Lynn, John A. 2006. "Revisiting the Great Fact of War and Bourbon Absolutism: The Growth of the French Army during the Grand Siècle" in García Hernán and Maffi (eds.).Madrid: Ediciones del Laberinto, Fundación Mapfre, CSIC.

[44] Mackay, Ruth. 1999. The Limits of Royal Authority: Resistance and Obedience in Seventeenth-Century Castile. Cambridge: Cambridge University Press.

[45] Mathias, Peter, and Patrick, O'Brien. 1976. "Taxation in Britain and France, 1715-1810. A Comparison of the Social and Economic Incidence of Taxes Collected for the Central Governments", The Journal of European Economic History, vol.5 (3): 601-650.

[46] Mauersberg, Hans. 1988. Finanzstrukturen deutscher Bundesstaaten zwischen 1820 und 1944. St. Katharinen: Scripta Mercaturae Verlag.

[47] Mccranie, Kevin. 2009. "The Recruitment of Seamen for the British Navy, 1793-1815" 'Why Don't You Raise More Men?"' in Stoker et al (eds.) Conscription in the Napoleonic Era.

[48] McEvedy, C. and R. Jones. 1978. Atlas of World Population History. New York: Facts on File.

[49] Ministry of Internal Affairs and Communications, Statistics Bureau. 2011. Historical Statistics of Japan, Chapter 2 Population and Household, Population by Sex, Population Increase and Decrease, Population Density (1872-2009).

[50] Murphey, Roads. 1999. Ottoman Warfare, 1500-1700. New Brunswick, NJ: Rutgers University Press.

[51] Nordmann, Claude. 1972. "L'armee suedoise au XVII siècle." La Revue du Nord, 54:133-147.

[52] Ogawa, Gotaro. 1921. Conscription System in Japan. New York: Oxford University Press. 
[53] Parrott, David. 2001. Richelieu's army: war, government and society in France, 1624-1642. Cambridge: Cambridge University Press.

[54] Pintner, Walter M. 1984. "The Burden of Defense in Imperial Russia, 1725-1914." Russian Review. 43(3): 231-259.

[55] Prasad, Devi and Tony Smythe, eds. 1968. Conscription: A World Survey: Compulsory Military Service and Resistance to It. London, UK: War Resisters' International.

[56] Quataert, D. 2000. The Ottoman Empire, 1700-1922. Cambridge: Cambridge University Press.

[57] Roberts, Michael. 1958. Gustavus Adolphus. London: Longman.

[58] Roberts, Michael. 1968. Sweden as a Great Power, 1611-1697: Government, Society, Foreign Policy. New York: St. Martin's Press.

[59] Roberts, Michael. 1973. Sweden's Age of Greatness: 1632-1718. London: Macmillan.

[60] Roberts, Michael. 1979. The Swedish Imperial Experience: 1560-1718. Cambridge: Cambridge University Press.

[61] Rothenberg, Gunther E. 1976. The Army of Francis Joseph. West Lafayette, Indiana: Purdue University Press.

[62] Sturgill, Claude C. 1991. "The French Army's Budget in the Eighteenth Century. A Retreat from Loyalty" in David G. Troyansky, Alfred Cismaru, and Norwood Andrews, Jr. (eds). Westport, CT: Greenwood Press.

[63] Tabakoglu, Ahmet. 1985. Gerileme Donemine Girerken Osmanli Maliyesi. Isantbul: Dergah Yayinlari.

[64] United States Government. 2006. Historical Statistics of the United States, vol. 5, Table Ed26-47, Military personnel on active duty, by branch of service and sex: 1789-1995, p. 5-353-359. Cambridge: Cambridge University Press.

[65] van Nimwegen, Olaf. 2006. The Dutch Army and the Military Revolutions, 1588-1688. Woodbridge: Boydell Press.

[66] Villstrand, Nils Erik. 2000. "Adaptation or Protestation Local Community Facing the Conscription of Infantry for the Swedish Armed Fources, 1620-1679." In ed., Leon Jeperson, .A Revolution from Above? The Power State of 16th and 17th Century Scandinavia. Odense: Odense University Press. 249-278.

[67] Von Stein, F. 1895. Geschichte der Entwickelung des russichen Heeres. Leipzig.

[68] Wildman, Allan. The End of the Russian Imperial Army. Princeton: Princeton University Press.

[69] Wilson, Peter. P. H. 1998. German Armies. War and German Politics. London; Bristol, PA: UCL Press. 
[70] Wilson, Peter. P. H. 2009. The Thirty Years War. Cambridge, MA: Harvard University Press.

[71] Wilson, Peter H. "Social Militarization in Eighteenth-Century Germany." German History. 18 (1): 1-39. 


\section{Institution Markets \\ IMT}

INSTITUTE FOR ADVANCED STUDIES LUCCA

2012 ( ) IMT Institute for Advanced Studies, Lucca Piazza San ponziano 6, 5100 Lucca, Italy. www.imtlucca.it 